\title{
Şiî Mezhepler Arasında İhtilaflı Bir Mesele: Müita Nikâhı
}

\begin{abstract}
Ahmet EKINCI
Atıf/Cite as: Ekinci, Ahmet. "Şiî Mezhepler Arasında İhtilaflı Bir Mesele: Müt'a Nikâhı". Recep Tayyip Erdoğan Üniversitesi Illahiyat Fakültesi Dergisi 20 (2021), 113-139.

Öz: Erkeğin kadına vereceği belirli bir bedel karşılığında belirli bir süre bir erkekle bir kadının karı-koca hayatı yaşamaları hususunda anlaşmaları şeklinde tanımlanan müt'a nikâhı, İslâm öncesi Arap toplumlarında var olduğu bilinen bir evlilik çeşididir. İslam'ın ilk yıllarında müt'a nikâhının Hz. Peygamber'in izniyle yapıldığı hususunda gerek Sünnî gerekse Şiî mezheplerin ittifakı bulunmaktadır. Konu hakkında yapılan ihtilaf ise Hz. Peygamber'in müt'a nikâhının sonradan yasaklayıp yasaklamadığ hususunda ortaya çıkmaktadır. Sünnî fıkıh mezhepleri yanı sıra Şiî Zeydîyye ve İsmâilîyye fıkıh mezheplerine göre de İslâm'ın ilk yıllarında zaruret hallerinde geçici olarak izin verilen müt'a nikâhı daha sonra yine bizzat Hz. Peygamber tarafından yasaklanmıştır. Ca'ferîler'e göre ise Hz. Peygamber, verdiği bu izni hiçbir zaman yasaklamamıştır. Müt'a nikâhını meşru gören Ca'ferîler'in konu hakkında ileri sürdügü delillerin başında Nisâ sûresi 24. ayeti yer almaktadır. Bu ayetin yanı sıra başvurdukları deliller arasında Hz. Peygamber ve imamlardan gelen rivayetler de bulunmaktadır. Müt'a nikâhının kabul edenlerle reddedenler arasında tartışma konularının başında Ca'ferîler'in dile getirdiği müt'a nikâhının gerek ayet gerekse hadislerle meşru kılınmasına karşın Hz. Ömer'in bu nikâhı yasaklaması ile Hz. Peygamber döneminde yapılan müt' a nikâhı ile Ca'ferîler' in kabul ettiği müt'a nikâhı arasındaki farklılıktır. Sünnî mezheplerin yanı sıra Zeydîyye mezhebi de $\mathrm{Hz}$. Peygamber zamanında yapılan müt'a nikâhının velinin gözetiminde iki şahidin huzurunda yapıldığı yönündeyken Ca'ferîler, müt'a nikâhında veli ve şahitleri gerekli görmemektedirler. Onlara göre küçükler dışındaki kadınlar velilerinin izin veya icazetine ihtiyaç duymaksızın müt'a nikâhında taraf olabilirler. Bu çalışmamızda Şiî fıkıh mezheplerinden Ca'feriyye, Zeydiyye ve İsmâiliyye'nin müt’a nikâhı hakkındaki görüşleri ele alınarak incelenecektir.
\end{abstract}

Anahtar kelimeler: Fıkıh, Müt'a, Ca'ferî, Zeydî, İsmâilî

* Dr. Öğr. Üyesi, Kafkas Üniversitesi, Kars, Türkiye, ahmedekinci@hotmail.com, ORCID: www.orcid.org/0000-0001-9765-1712 


\title{
A Controversial Subject Among Shia Sects: Mut‘ah Marriage
}

\begin{abstract}
Muta (temporary) marriage, which is defined as a man and a woman agreeing to live a husband-and-wife life for a certain period of time for a certain price to be given to the woman, is a type of marriage known to exist in preIslamic Arab societies. It is accepted by both Sunni and Shiite sects that muta marriage was legalized with the permission of the Prophet Muhammad (peace be upon Him) in the first years of Islam. The dispute over the subject arises as to whether the muta marriage was later banned by Prophet Muhammad. According to the Sunni fiqh sects as well as the Shiite Zaydiyye (Zaidi) and Ismaili fiqh sects, muta marriage, which was temporarily allowed in the first years of Islam in case of necessity, was later banned by Prophet Muhammad himself. According to the Jafarites, the Prophet never banned this permission. The 24th verse of the An-Nisa surah (meaning: The Women) is one of the evidences put forward by the Jafarites, who consider muta marriage is permissible. In this study, the views of Jafarite, Zaydiyye and Ismaili sects of Shiite fiqh about the muta marriage will be examined.
\end{abstract}

Keywords: Fiqh, Mut'ah, Jafarite, Zaydiyye, Ismaili

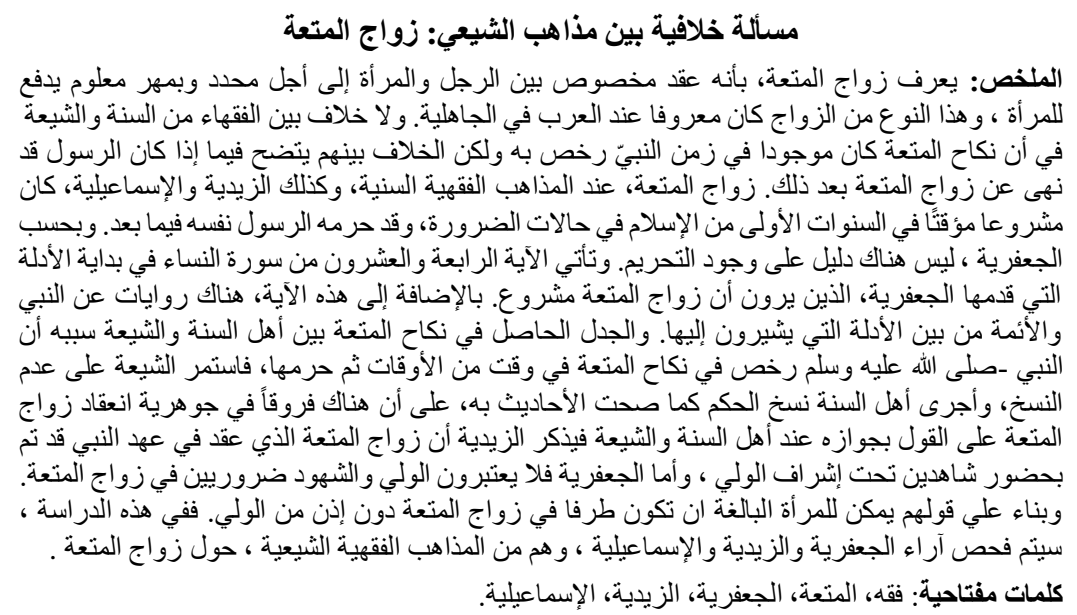

\section{GİRiş}

Sözlükte "menfaat, faydalanma"1 anlamlarına gelen müt’a, bir fıkıh terimi olarak belli bir ücret karşılığında belli bir süreliğine yapılan geçici evliliği ifade etmek için kullanılmaktadır. ${ }^{2}$ İslâm öncesi Arap toplumlarında var olduğu bilinen müt’a nikâhı, ${ }^{3}$

1 Muhammed b. Ebû Bekir Râzî, Muhtârü's-sihâh (Beyrut: Mektebetü'1-Asriyye, 1420), “m-t-a”, 290; Muhammed b. Mükerrem b. Ali b. Ahmed İbn Manzûr, Lisânü'l-Arab (Beyrut: Dâru Sâdır, 1414), “Müt'a", 8/329; Muslihuddin Mustafa Ahterî, Ahterî-i keb̂̂r (İstanbul: Matbaatu Âmire, 1310), "Müt'a", 257.

2 Muhammed b. Muhammed b. en-Nu'mân Şeyh Müfîd, Hülâsatü'l-îcâz (Beyrut: Dârü'l-Müfîd, 1414), 19.

3 Yahya b. Hüseyin Hâdî-İlelhak, Kitâbü'l-ahkâm fi'l-helâl ve'l-harâm, thk. Murtazâ b. Zeyd Mahatvarî (San'a: Mektebetü Bedr, 2014), 1/309; Ebû Bekr Ahmed b. el-Hüseyn b. Ali Beyhakî, es-Sünenü'lkübrâ, thk. Muhammed Abdulkadir Ata (Beyrut: Dâru'1-Kütübi'l-İlmiyye, 1424), 7/335; Ali Cevâd, 
genellikle bir kabilenin himayesine girme ihtiyacı duyan yabancı erkek ile himaye talep ettiği kabileden bir kadın arasında yapılırdı. Nikâh akdinden sonra kadın, erkeğe bir mızrak ve bir çadır verir ve nikâh akdi devam ettiği müddetçe erkek kabilenin bir üyesi gibi kabul edilirdi. Erkek bu nikâh akdiyle himaye edilmenin yanı sıra eşyalarını koyabileceği bir yer edinir ve bu süre içinde kadınla, evlilik hayatı yaşardı. Bu tür evliliklerde kadın kendi kabilesi içerisinde kalmaya devam eder ve evlilikten doğacak çocuk kadına nispet edilirdi. Kadın evliliği sonlandırmak istediğinde çadırın kapısının yerini değiştirir bu şekilde koca da evliliğin sonlandırıldığını anlar ve böylece kabileden ayrılırdı. ${ }^{4}$

İslam'dan önce varlığı bilinen müt'a nikâhının Hz. Peygamber'in izniyle yapıldığı hususunda gerek Sünnî gerekse Şiî mezhepleri arasında ittifak bulunmaktadır. Konu hakkındaki ihtilaf ise Hz. Peygamber'in müt'a nikâhının sonradan yasaklayıp yasaklamadığı hususunda ortaya çıkmaktadır. Sünnî fıkıh mezhepleri yanı sıra Şiî Zeydîyye ve İsmâilîyye fıkıh mezheplerine göre de Hz. Peygamber, öncesinde müsaade ettiği müt’a nikâhını daha sonra yasaklamıştır. Ca'ferîler'e göre ise Hz. Peygamber'in verdiği bu izin herhangi bir şekilde yasaklanmamıştır. Ca'ferîler'e göre müt’a nikâhı ameli bir hüküm olmakla birlikte aynı zamanda onların inanç esasları arasında da yer almaktadır. Nitekim İmam Rızâ'nın Me'mûm'a yazdığı iddia edilen bir mektupta yer alan “Halis İslam, Allah'tan başka ilah olmadığına...Kur'an'da varlığı bilinen ve Hz. Peygamber'in sünneti olan müt'a nikâhı ve müt'a haccının helal olduğuna inanmaktır."5 ifadeleri müt'a nikâhının inanç esaslarından olduğunu göstermektedir.

Müt'a nikâhını meşru gören Ca'ferîler'in konu hakkında ileri sürdüğü delillerin başında Nisâ sûresi 24. ayeti yer almaktadır. Bu ayetin yanı sıra başvurdukları deliller arasında gerek Hz. Peygamber'den gerekse Hz. Ali ile Muhammed Bâkır ve Ca'fer esSâdık'tan yapılan rivayetler de bulunmaktadır. Konu hakkında araştırma yapan bazı araştırmacılar tarafından ise müt'a nikâhının meşruiyetini Ca'ferîler'in sırf dini delil ve siyasi tutumlarıyla tatmin edici bir şekilde açıklanmanın yeterli olmadığı, farklı etkenlerin de Ca'ferîler'in müt'a nikâhını benimsemelerinde belirleyici olduğu

el-Mufassal (Beyrut: Dâru's-Sâkî, 2001), 8/220; Şehlâ Hâirî, el-Müt 'a ez-zevâcü'l-müekkat inde'ş-Şî́a, hâletü İran 1978-1982, çev. Fâdî Hammûd (Beyrut: Şirketü'l-Matbûat, 2007), 81.

4 Beyhakî, es-Sünenü'l-kübrâ, 7/335; M. Şemseddin Günaltay, "Kable'l-İslâm Araplarda İctimâî Aile”, Darülfünun İlahiyat Fakültesi Mecmuası 1/4 (1926), 91-92; Hâirî, el-Müt 'a ez-zevâcü'l-müekkat inde'şŞî'a, hâletü Íran 1978-1982, 81; Konu hakkında ayrıntılı bir çalışma için bk. M. K. Abdüssamet Bakkaloğlu, Câhiliye Dönemi Âile Hukuku (İstanbul: Marmara Üniversitesi, Yüksek Lisans, 1995), 71 vd; Süleyman Yılmaz, Ehl-i Sünnet ve Şî̀ Caferî Müfessirlerine Göre Mut'a Nikâhı (Yozgat: Bozok Üniversitesi, Yüksek Lisans, 2017), 23 vd; Adnan Demïrcan, “Cahiliye ve Hz. Peygamber Dönemi Uygulamalarıyla Nikâh”, Diyanet İlmi Dergi 49/3 (01 Eylül 2013), 37-39.

5 Muhammed b. el-Hasen b. Ali Hür el-Âmilî, Vesâ'ilü'ş-Şîa (Tahran: Mektebetü'l-İslâmiyye, 1397), $14 / 439$. 


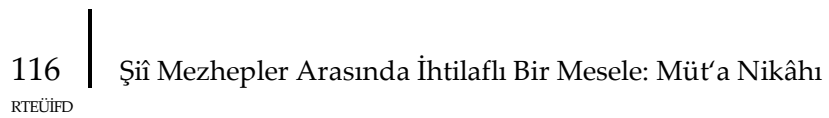

belirtilmektedir. Bu iddiayı savunanlara göre $\mathrm{Ca}^{\prime}$ ferîler, siyasi muhalifleri tarafından zulme uğrayan, hapsedilen, sürgüne gönderilen veya ailelerinden zorla ayrılmaya maruz bırakılan küçük bir azınlık gruptu. Bu gibi endişelerden ötürü Ca'ferîler aile sorumluluğundan veya bağlılıklarından endişe duymaktaydılar. Nitekim sürekli evlilikler bu gibi koşullar altında her zaman mümkün değildi. Evlilik dışında diğer tüm cinsel ilişki biçimlerinin İslam'da yasak olmasından dolayı Ca'ferîler aile hayatıyla ilgili olarak daha küçük sorumluluklar ve riskler içeren müt’a nikâhını tercih etmek durumunda kalmışlardır. ${ }^{6}$

Müt’a nikâhı konusunda yapılan tartışmaların başında Ca'ferîler'in dile getirdiği müt’a nikâhının gerek ayet gerekse hadislerle meşru kılınmasına karşın Hz. Ömer'in bu nikâhı yasaklaması ve kendileri dışındaki çoğunluğun da bu yasaklamayı kabul etmesi yer almaktadır. Müt’a nikâhı hakkında yapılan bir diğer tartışma konusu ise Hz. Peygamber döneminde yapılan müt’a nikâhı ile Ca'ferîler'in kabul ettiği müt’a nikâhı arasındaki farklılıktır. Sünnî mezheplerin yanı sıra Zeydîyye mezhebi de Hz. Peygamber zamanında yapılan müt’a nikâhının velinin gözetiminde iki şahidin huzurunda yapıldığı yönündeyken Ca' ferîler, müt’a nikâhında veli ve şahitleri gerekli görmemektedirler. Onlara göre küçükler dışındaki kadınlar velilerinin izin veya icazetine ihtiyaç duymaksızın müt'a nikâhında taraf olabilirler.7

Müt’a nikâhı hakkında kapsamlı bir araştırma yapan Şehlâ Hâirî, müt’a nikâhının günümüzdeki şekline kavuşmasının tedrici bir seyirle gerçekleştiğini kaydetmektedir. Hâirî, Kur'ân ve sünnette müt’a nikâhının hükümlerini belirleyen açıklayıcı bir bilgi bulunmadığı için müt‘a evliliğinin çerçevesinin devamlı nikâhla cariyelerle evlilik hükümleri doğrultusunda Şî̂ fakihler tarafından icâre (kira) akdi çerçevesinde belirlendiğini ifade etmektedir. Hâirî bu bağlamda müt’a evliliği müessesesinin mevcut şekline kavuşmasında başta Ca'fer es-Sâdık olmak üzere Şiî Ca'ferî imam ve fakihlerince gerçekleştirilen tartışmaların belirleyici olduğunu kaydetmektedir. ${ }^{8}$

Ca'ferîler müt’a nikâhını “Erkeğin kadına vereceği belirli bir bedel karşılığında belirli bir süre bir erkekle bir kadının karı-koca hayatı yaşamaları hususunda

6 Hammûdah 'Abd al-Atî, The Family Structure in İslam, ts., 105-106.

7 Ebü'l-Kâsım Necmüddîn Ca'fer b. el-Hasen b. Ebî Zekeriyyâ Yahyâ Hillî, el-Muhtasar (Bağdat: Mektebetü'l-Ehliyye, 1383), 207-208; Ebû Ca'fer Muhammed b. el-Hasen b. Ali Tûsî, el-İstibsâr, thk. Seyyid Hasan Mûsevî (Necef: Dâru'l-Kütübi'l-İslamiyye, 1376), 3/147, 150-151; Şeyh Müfîd, Hülâsatü'l-îcâz, 46-47, 51-53; Muhammed b. Muhammed b. en-Nu'mân Şeyh Müfîd, Risâletü'lmüt'a (Beyrut: Dârü'l-Müfîd, 1414), 10, 12-13; Ali b. el-Hüseyin b. Musa b. Muhammed Şerif elMurtazâ, el-İntisâr (Kum: Menşûrâtü'ş-Şerif el-Murtaza, 1391), 125.

8 Hâirî, el-Müt' $a, 83$. 
anlaşmaları" $^{\prime \prime}$ şeklinde tanımlamaktadırlar. Onlara göre müt‘a nikâhının hedefi erkekle kadın arasında cinsel tatminin meşru bir şekilde sağlanmasıdır. ${ }^{10}$ Şehlâ Hâirî, içerisinde bazı fakihlerin de bulunduğu İran halkının çoğunluğunun inandığının aksine müt’a evliliğinin müminlerin refahını sağlamak üzere İslâm’ın icat ettiği bir çözüm olmadığını, Câhiliye döneminde bazı Arap kabilelerince uygulanan kadim bir âdet olduğunu ifade etmektedir. ${ }^{11}$ Günümüzde İran' da devlet desteğiyle uygulamada olan müt'a nikâhı İran dışında Suriye, Irak ve Lübnan Ca'ferîleri tarafından da câiz kabul edilmekle birlikte uygulamasına sıcak bakılmamaktadır. Örneğin; Lübnan'da bulunan Ca'ferî mahkemeleri müt'a nikâhına izin vermediği gibi bu yolla yapılan nikâh akdini de geçerli kabul etmemektedir. ${ }^{12}$ Hâirî, Ca' fer eş-Şehîdî' den naklen müt'a nikâh uygulamasının diğer bölgelere nispeten İran' da çok yaygın bir şekilde yapılıyor olmasında 1796-1925 yılları arasında İran yönetimini elinde bulunduran Kaçar ailesinin müt'a nikâhına müsamahalı yaklaşımları ve bu ailenin müt’a nikâhı yapmalarının etkili olduğunu belirtmektedir. ${ }^{13}$

Ca'ferî mezhebinde müt'a nikâhının, İran' da en yaygın uygulama alanı bulan ve çalışma konumuzu oluşturan dini müt’a nikâhı, Kum vb. yerleri ziyaret etmek için arkadaş edinme yoluyla yapılan müt’a nikâhı, ${ }^{14}$ kadının isteğinin yerine gelmesi durumunda yapmayı adadığı ve genellikle seyyid olan bir din adamıyla nikâhlanma şeklinde gerçekleştirilen nezir müt'ası, ${ }^{15}$ eşinden kaynaklı çocuğu olmayan kocanın çocuk sahibi olmak için yaptığı müt'a nikâhı, ${ }^{16}$ çalıştı̆̆ 1 evde veya iş yerinde cinsel birliktelik olmamak şartıyla sadece erkekten mahremliği kaldırmak üzerine yapılan müt'a nikâhı, ${ }^{17}$ evlilik görüşmeleri öncesinde erkeğin kadının yüzünü daha rahat görmesini sağlamak amacıyla yapılan müt'a nikâhı, ${ }^{18}$ teberrük amacıyla zifaf öncesi gelin ve damadın bir din büyüğünün mezarı başında geleneksel bir merasimle müt’a yoluyla evlendirildikleri mezar müt'ası, dâimî nikâhla evli kadının kendi yükünü hafifletmek üzere hem hizmetçi hem geçici kuma sıfatıyla kocası için bizzat muvakkat

9 Şeyh Müfîd, Hülâsatü'l-îcâz, 19; Seyyid Kazım Tabatabaî, “ez-Zevâcü'l-müekkat tarîkun şer'î liteârufi'z-zevceyni kable'n-nikâhi'd-dâim”, Dinlerde Nikâh Milletlerarası Tartışmalı İlmî Toplantı (İzmir, 2012), 508.

10 Hâirî, el-Müt'a, 82-83.

11 Hâirî, el-Müt' $a, 81$.

12 Muhammed Cevad Muğniyye, el-Fıkh ale'l-mezâhibi'l-hamse (Tahran: Müessesetü's-Sâdık, ts.), 367.

13 Hâirî, el-Müt' $a, 116$.

14 Hâirî, el-Müt' $a, 121$.

15 Hâirî, el-Müt'a, 121-122.

16 Hâirî, el-Müt'a, 131.

17 Şeyh Müfîd, Hülâsatü'l-îcâz, 55-56; Hâirî, el-Müt' 'a, 135.

18 Hâirî, el-Müt' 'a, 87. 
118 Şiî Mezhepler Arasında İhtilaflı Bir Mesele: Müt‘a Nikâhı

nikâhla evleneceği eş seçmesi yoluyla gerçekleşen müt‘a nikâhı gibi birden çok çeşidi bulunmaktadır. ${ }^{19}$

İan toplumunda muvakkat evlilik her ne kadar kadına daha serbest davranma imkânı verse de müt’a nikâhı yapan kadınlar toplum nezdinde kötü yola düşmüş olarak telakki edilmektedir. Örneğin; İran toplumunda müt‘a nikâhı yapan kadınlar için hor görme, küçümseme ve tahkir anlamı içeren "sîgıyye" kelimesi kullanılmaktadır. ${ }^{20} \mathrm{Bu}$ da müt'a evliliği hakkında dinî öğretilerle halk arasında çelişkili bir durumun bulunduğunu ortaya koymaktadır. Nitekim halk, Ca'ferî mezhebinde ibadet telakki edilen müt'a nikâhı ile fuhuş arasında bağ kurduğundan bu nikâhı olumlu karşılamamaktadır. ${ }^{21}$ Bunun bir sonucu olarak da müt'a nikâhı yapanlar bu ilişkiyi gizli tutmakta, müt'a nikâhı yapan kadınlar da aileleri tarafından cezalandırılmaktadır. ${ }^{22}$ Ayrıca müt'a nikâhının İranlı kadınların erkek himayesi ve sosyal saygınlık gibi beklentilerini karşılamadığı da ifade edilmektedir. Bundan dolayı da birçok kadının müt’a nikâhına dâimî evlilik beklentisi veya erkeğin bu yöndeki verdiği söze binaen razı olduğu belirtilmektedir. ${ }^{23}$ Bunun yanı sıra müt’a nikâhının gerekli bir müessese olduğunu savunup ve bu nikâhı sevap kazanmaya vesile olan bir ibadet olduğuna inanan az sayıda kadına rastlandığı da ifade edilmektedir. ${ }^{24}$ İran'da kadınları müt'a nikâhı yapmaya sevk eden etkenler konusunda yapılan şu tespit ayrıca bir önemi haizdir; “fakir kadınlar, müt’a nikâhını maddi ihtiyaçlarını karşılamak için yaparken zengin kadınlar ise cinsel isteklerinin veya cinsel ihtiyaçlarının karşılanması için müt'a nikâhı yapmaktadır. ${ }^{25}$

Müt’a nikâhı hakkında ülkemizde birçok çalışma yapılmakla birlikte Şiî fıkıh mezhepleri bağlamında müt'a nikâhını ele alıp inceleyen bir çalışma bulunmamaktadır. ${ }^{26}$ Çalışmamızda Şiî fıkıh mezheplerinden Ca' feriyye, Zeydiyye ve

19 Hâirî, el-Müt 'a, 133-137, 254, 262; Saffet Köse, "Ca'ferîlikte Mut'a ve Ona Karş1 Sünnî Duruş”, Marife 3 (2008), 96.

20 Hâirî, el-Müt' $a, 83$.

21 Hâirî, el-Müt' $a, 277$.

22 Hâirî, el-Müt' $a, 322$.

23 Hâirî, el-Müt 'a, 278-279.

24 Hâirî, el-Müt 'a, 284-285.

25 Hâirî, el-Müt' $a, 262$.

26 Müt'a nikahı konusunda yapılan çalışmalar için bk. Köse, “Ca'ferîlikte Mut'a ve Ona Karşı Sünnî Duruş"; Osman Kaşıkçı, "Mut'a Nikâhı", Türk Hukuk Tarihi Araştırmaları 3 (2007), 43-58; Adalet Çakır, Mut'a Nikahının Tarihi Gelişmesi ve İslâm Hukukundaki Yeri (İstanbul: Marmara Üniversitesi, Yüksek Lisans, 1994); Yasemin Meşinci, Mut'a Nikahı ile İlgili Hadislerin Tespit ve Tenkidi (Adana: Çukurova Üniversitesi Sosyal Bilimler Enstitüsü, Yüksek Lisans Tezi, ts.); Mustafa Öztürk, “Sünni ve Şii Kaynaklarda Mut'a Nikâhı Tartışması", İslâmiyât 8/3 (2005), 95-120; Sayın Dalkıran, “İmamiyye Şı̂ası'nın Mut'a Nikahı Uygulamasına Karşı Ahmet Feyzi'nin Eleştirileri”, Atatürk Üniversitesi İlahiyat Fakültesi Dergisi 27 (2007), 1-16; İbrahim Canan, Namus Fitnesi Mut'a Nikâhı (İstanbul: Timaş Yayınları, 2011); Demïrcan, “Cahiliye ve Hz. Peygamber Dönemi Uygulamalarıyla Nikâh"; Yılmaz, Ehl-i Sünnet ve Şî̀ Caferî Müfessirlerine Göre Mut'a Nikâhı. 
İsmâiliyye'nin müt'a nikâhına bakışlarını ortaya koymak amacıyla sadece bu üç Şiî fıkıh mezhebinin görüşüne yer verilecektir. Araştırmamızın alt yapısını oluşturmak için öncelikle ana hatlarıyla Şiî fıkıh mezheplerinde evlenme ve boşanmayla ilgili hükümlere dair bilgiler verilecektir. Ardından müt’a nikâhının caiz olduğunu savunan Ca'ferîler'in konu hakkındaki görüş ve delillerine yer verilecek ve onlara göre müt’a nikâhının unsur ve şartları ele alınacaktır. Ardından müt’a nikâhını caiz görmeyen Zeydî ve İsmâilî fıkıh mezheplerinin görüşlerine ve delilleri ele alınacaktır. Çalışma, elde edilen bulguların değerlendirildiği sonuç bölümüyle tamamlanacaktır.

\section{1. Şiî Fıkıh Mezheplerinde Nikâh Akdinin Unsurları}

\subsection{Evlenme Engelinin Bulunmaması}

Şiî fıkıh mezheplerine göre ana hatlarıyla evlenme engelleri yedi tanedir. Nesepten kaynaklı evlenme engeli, ${ }^{27}$ süt hısımlığından kaynaklı evlenme engeli, ${ }^{28}$ evlilikten kaynaklı evlenme engeli, ${ }^{29}$ dört eşle evli olmaktan kaynaklı evlenme engeli, ${ }^{30}$ liândan kaynaklı evlenme engeli, ${ }^{31}$ din farkından kaynaklı evlenme engeli ${ }^{32}$ ve ihramdan dolayı evlenme engeli: Şiî mezheplerin üçüne göre de ihramlı olan nikâh kıyamadığı gibi kendisi de nikâh akdinde taraf olamaz. İhramlının yaptığı nikâh akdi batıldır. ${ }^{33}$

\section{2. İrade Beyanı}

İrade beyanı icab ve kabulden oluşmaktadır. Ca'ferî mezhebinde sahih olan görüşe göre kadının baliğ ve reşit olması durumunda icab ve kabulün veli tarafından

27 Hillî, el-Muhtasar, 200; Nu'mân b. Ebî Abdillah Muhammed b. Mansûr Kadı Nu'mân, De'âimü'lİslâm, thk. Asıf b. Ali Feyzî (İskenderiyye: Dâru'l-Meârıf, 1383), 2/232; Hâdî̀̇lelhak, Kitâbü'l-ahkâm fi'l-helâl ve'l-harâm, 1/300; Muhammed b. Ali b. Hüseyin Alevî, el-Câmi'u'l-kâfî fî fikhi'z-Zeydiyye (Yemen: Müessesetü'l-Mustafa es-Sekafiyye, 2014), 4/11.

28 Hillî, el-Muhtasar, 200; Hâdî-İlelhak, Kitâbü'l-ahkâm fi'l-helâl ve'l-harâm, 1/301; Kadi Nu'mân, De'âimü'l-İslâm, 2/239; Nu'mân b. Ebî Abdillah Muhammed b. Mansûr Kadı Nu'mân, İktisâr (Beyrut: Dâru'1-Evdâ', 1416), 82.

29 Hillî, el-Muhtasar, 2020; Hâdî-İlelhak, Kitâbü'l-ahkâm fi'l-helâl ve'l-harâm, 1/301-302; Alevî, elCâmi'u'l-kâfî fî fikhi'z-Zeydiyye, 4/11-13; Kadı Nu'mân, De'âimü'l-İslâm, 2/232-234; Kadı Nu'mân, İktisâr, 81.

30 Hillî, el-Muhtasar, 204; Kadı Nu'mân, De'âimü'l-İslâm, 2/235; Hâdî-İlelhak, Kitâbü'l-ahkâm fi'l-helâl ve'l-harâm, 1/297.

31 Hillî, el-Muhtasar, 204-205; Hâdî-İlelhak, Kitâbü'l-ahkâm fi'l-helâl ve'l-harâm, 1/416; Kadı Nu'mân, Déâimü'l-İslâm, 2/282.

32 Hillî, el-Muhtasar, 205; Şerif el-Murtazâ, el-İntisâr, 117; Kadı Nu'mân, İktisâr, 84; Kadı Nu'mân, De'âimü'l-İslâm, 2/249-250; Hâdî-İlelhak, Kitâbü'l-ahkâm fi'l-helâl ve'l-harâm, 1/336-337; Alevî, elCâmi'u'l-kâfi fì fikhi'z-Zeydiyye, 4/19-20.

33 Hâdî-İlelhak, Kitâbü'l-ahkâm fi'l-helâl ve'l-harâm, 1/264; Kadı Nu'mân, De'âimü'l-İslâm, 2/237; Ebü'lKâsım Necmüddîn Ca'fer b. el-Hasen b. Ebî Zekeriyyâ Yahyâ Hillî, Şerâ'i'u'l-İslâm, thk. Seyyid Sâdık Şîrâzî (Beyrut: Müessesetü'l-Vefâ, 1409), 1/184. 
120 Şiî Mezhepler Arasında İhtilaflı Bir Mesele: Müt’a Nikâhı

yapılması şart değildir. ${ }^{34}$ Zeydî ve İsmâilîler'e göre ise nikâh akdinde icab ve kabul kadının velisi tarafından yapılmadır. ${ }^{35}$

\subsection{Rizanın Bulunması}

Nikâh akdinde mükellef yani akil-baliğ bekâr veya dul kadının rızası gerekliyken küçüklerin ve delilerin evlendirilmesinde bunların rızaları gerekli görülmemektedir. ${ }^{36}$

\subsection{Veli}

Ca'ferî mezhebinde sahih görüşe göre baliğ ve reşit kadın, velisinin izni aranmaksızın nikâh akdinde akdin tarafı olabilir. ${ }^{37}$ Mezhepte evla olan görüş ise müt’a nikâhında gerekli görülmeyen veli izninin devamlı evlilik akdinde gerekli olduğu yönündedir. ${ }^{38}$ Zeydî ve İsmâilîler'e göre nikâh akdinde velinin bulunması şarttır. Veli dışında kıyılan nikâh batıldır. ${ }^{39}$

\section{5. Şahitler}

İsmâillîler'e göre nikâh akdinde şahitlerin bulunması nikâh akdinin sıhhat şartı olmayıp kadının hakkını korumaya matuf yapılan bir uygulamadır. ${ }^{40}$ Zeydîler'e göre nikâh akdinin sahih olabilmesi için yapılan akitte en az iki adil şahidin bulunması gerekmektedir. ${ }^{41}$ Ca'ferî mezhebinde sahih olan görüşe göre kadının baliğ ve reşit olması durumunda nikâhta şahitlerin bulunması zorunlu değildir. ${ }^{42}$

34 Hillî, el-Muhtasar, 194-195; Tûsî, el-İstibsâr, 3/146.

35 Ahmed b. Kasım el-Ansî Sanânî, et-Tâcü'l-müzheb li ahkâmi'l-mezheb Şerhu Metni'l-Ezhâr (Yemen: Dâru'l-Hikmeti'1-Yemâniyye, 1414), 2/22-26; İbnü'1-Murtazâ, el-Bahru'z-zehhâr (Beyrut: Dâru'1Kütübi'l-İlmiyye, 2001), 4/32-33,37, 41, 44; Alevî, el-Câmi'u'l-kâfî fî fikhi'z-Zeydiyye, 4/254 vd; Kad1 Nu'mân, De'âimü'l-İslâm, 2/218.

36 Kadı Nu'mân, De'âimü'l-İslâm, 2/218; Kadı Nu'mân, İktisâr, 80; Hillî, el-Muhtasar, 194-195; Hâdîİlelhak, Kitâbü'l-ahkâm fi'l-helâl ve'l-harâm, 1/304-305; Sanânî, et-Tâcü'l-müzheb li ahkâmi'l-mezheb Şerhu Metni'l-Ezhâr, 2/35-37.

37 Şerif el-Murtazâ, el-İntisâr, 119-120; Tûsî, el-İstibsâr, 3/146; Hillî, el-Muhtasar, 194-195.

38 Hillî, el-Muhtasar, 198.

39 Zeyd b. Ali Zeyd, el-Mecmû 'u'l-hadîsî ve'l-fikhî, thk. Abdullah b. Hamûd el-İzzî (Yemen: Mektebetü İmam Zeyd b. Ali, 2002), 211; Hâdî-İlelhak, Kitâbü'l-ahkâm fi'l-helâl ve'l-harâm, 1/302-305; Kadı Nu'mân, De'âimü'l-İslâm, 2/218-219; Kadı Nu'mân, İktisâr, 80; İbnü'l-Murtazâ, el-Bahru'z-zehhâr, $4 / 50$.

40 Kadı Nu'mân, De'âimü'l-İslâm, 2/219-220.

41 Sanânî, et-Tâcü'l-müzheb li ahkâmi'l-mezheb Şerhu Metni'l-Ezhâr, 2/31; İbnü'1-Murtazâ, el-Bahru'zzehhâr, 4/47-48; Alevî, el-Câmi'u'l-kâfî fî fikhi'z-Zeydiyye, 4/54 vd.

42 Şerif el-Murtazâ, el-İntisâr, 118; Tûsî, el-İstibsâr, 3/146; Hillî, el-Muhtasar, 195. 


\subsection{Mehir}

Mehir, nikâh akdinin bir sonucu olarak kocanın eşine ödemek zorunda olduğu para, mal veya menfaattir. Üç Şiî mezhebine göre mehrin belirlenmesi nikâh akdinin şartı olmayıp yapilan akdin bir sonucudur. ${ }^{43}$

\section{2. Şiî Fıkıh Mezheplerinde Evliliğin Sona Ermesi}

\subsection{Boşama Salahiyeti ve Ehliyet}

Talakın mükellef yani akil-baliğ olan koca veya vekili tarafından verilmesi gerekmektedir. Zeydîler'e göre küçük ve deli adına velilerinin verdiği talak geçersizdir. ${ }^{44}$ Şî̂ mezheplere göre boşama kocanın kendi istek ve iradesiyle gerçekleşmesi gerekmektedir. Dolayısıyla tehdit ve zorlama altında yapılan talaklar geçersizdir. ${ }^{45}$ Ayrıca Ca'ferîler'e ve İsmâilîler'e göre boşamalarda şahitlerin bulunması zorunludur. Verilen talakın iki adil şahidin huzurunda yapılması gerekmektedir. Bu bağlamda şahitsiz veya tek şahitle yapılan talak geçersizdir. ${ }^{46}$

\subsection{Boşama Çeşitleri}

Ca'ferî ve Zeydîler'e göre talak sünnî ve bid'î olmak üzere iki kısma ayrılmaktadır. İsmâilîler'e göre ise talak sünnî, bid'î ve iddet talakı olmak üzere üçe ayrılmaktadır. Ca'ferîler sünnî talakı da kendi içerisinde bâin, ric'î ve iddet talakı olmak üzere üç kısma ayırmaktadırlar. Zeydîler'e göre bid'î talak haram olmakla birlikte geçerliyken Ca'ferî ve İsmâilîler'e göre bid'î talak geçerli değildir. ${ }^{47}$

İsmâilî ve Ca'ferîler'e göre iddet talakı, erkeğin her üç talakta da cinsel birlikteliğin olmadığı temizlik döneminde eşini adil iki şahit huzurunda boşaması ve hayız olmadan önce yine iki şahit huzurunda eşine geri dönüp cinsel birliktelik yaşaması şeklinde gerçekleşir. ${ }^{48}$

43 Kad1 Nu'mân, De'âimü'l-İslâm, 2/221; Kadı Nu'mân, İktisâr, 80; Hillî, el-Muhtasar, 214; Muhammed b. Ali b. Hüseyin İbn Bâbeveyh, Men lâ yahduruhü'l-fakîh (Beyrut: Müessesetü'l-A'lemî li'lMetbûat, 1406), 3/261; Sanânî, et-Tâcü'l-müzheb li ahkâmi'l-mezheb Şerhu Metni'l-Ezhâr, 2/40; Şerif elMurtazâ, el-íntisâr, 124 .

44 Sanânî, et-Tâcü'l-müzheb li ahkâmi'l-mezheb Şerhu Metni'l-Ezhâr, 2/118-119; Tûsî, el-İstibsâr, 3/278.

45 Hillî, el-Muhtasar, 221; Sanânî, et-Tâcü'l-müzheb li ahkâmi'l-mezheb Şerhu Metni'l-Ezhâr, 2/118-119; Kâdı Nu'mân, İktisâr, 87; Kâdı Nu'mân, Deâimü'l-İslâm, 2/261, 268.

46 Kadı Nu'mân, De'âimü'l-İslâm, 2/259-260; Kadı Nu'mân, İktisâr, 86, 87; Şerif el-Murtazâ, el-İntisâr, 127-128; Hillî, el-Muhtasar, 222.

47 Kadı Nu'mân, İktisâr, 86, 87; Hillî, el-Muhtasar, 222, 223; Sanânî, et-Tâcü'l-müzheb li ahkâmi'l-mezheb Şerhu Metni'l-Ezhâr, 2/124-125, 126-127.; Tûsî, el-İstibsâr, 3/285, 294; Şerif el-Murtazâ, el-İntisâr, 134.

48 Kadı Nu'mân, De'âimü'l-İslâm, 2/258-259; Kadı Nu'mân, İktisâr, 86; Hillî, el-Muhtasar, 223; Hillî, Şerâ'i'u'l-İslâm, 3/589. 
122 Şiî Mezhepler Arasında İhtilaflı Bir Mesele: Müt‘a Nikâhı

\section{3. Şiî Fıkıh Mezheplerine Göre Müt’a Nikâhı}

Şiî fıkıh mezhepleri arasında müt’a nikâhını yalnızca Ca'ferîler caiz görmekte Zeydî ve İsmâilî fıkıh mezhepleri ise başlangıçta izin verilen müt'a nikâhının $\mathrm{Hz}$. Peygamber tarafından yasaklandığını ve kadına verilmesi gereken $1 / 4$ veya $1 / 8$ hisse payını gösteren miras ayetleriyle bu nikâhın neshedildiğini ifade etmektedirler. Bu başlık altında öncelikli olarak müt’a nikâhını caiz gören Ca'ferîler'in konu hakkında ileri sürdükleri delillere ardından müt’a nikâhının rükün ve şartlarına yer verilecektir. Daha sonra Zeydiyye ve İsmâiliyye mezheplerinin müt'a nikâhı hakkındaki görüşleri ile bu nikâhın yasaklandığına dair ileri sürdükleri deliller ele alınacaktır.

\subsection{Ca'ferî Mezhebi}

Ca'ferîler'e göre müt‘a nikâhı, erkeğin kadına vereceği belli bir ücret karşılığında belli bir süreliğine karı-koca hayatı yaşamalarını sağlayan bir icâre akdidir. ${ }^{49}$ Ca'ferîler, müt'a nikâhının Hz. Peygamber'in izniyle meşru olduğu hususunda ümmetin icmâının bulunduğunu, ihtilafın ise verilen bu iznin sonradan kaldırılıp kaldırılmadığı meselesinde ortaya çıtığını belirtmektedirler. İmamiyye Şı̂a'sına göre Hz. Peygamber tarafından verilen bu izin kaldırılmamıştır. Onlara göre sahabeden Hz. Ali (ö. 40/661), Hz. Hasan (ö. 49/669) ve Hz. Hüseyin (ö. 61/680) ile İbn Abbâs (ö. 68/687-88) ve İbn Mes'ûd (ö. 32/652-53) gibi ümmetin seçkin âlimlerinin görüşü bu yöndedir. Ayrıca tabiînden Zeynelâbidîn (ö. 94/712), Muhammed Bâkır (ö. 114/733), Câ'fer es-Sâdık (ö. 148/765), Tâvûs (ö. 106/725) ve Mücâhid (ö. 103/721) gibi âlimlerin de bu görüşü savunduklarını ve sonraki Ca'ferî imamların da bu görüşte icmâ ettiği belirtilmektedir.50 Onlara göre müt'a nikâhı Allah ve Resûlü tarafından helal kılınmasına rağmen Hz. Ömer (ö. 23/644) tarafından yasaklanmıştır. ${ }^{51}$ Ca'ferîler'e göre müt'a nikâhı yapmak sünnettir. Konu hakkında Ca'fer es-Sâdık'tan yapılan “Erkeklerin müt'a nikâhı yapması müstehaptır. Ömründe bir defa mut'a yapmadan dünyadan giden (ölen) erkeğe güzel bakmam"52 gibi birçok rivayetler de bunu teyit etmektedirler. Şeyh Müfid'in (ö. 413/1022) müt'a nikâhı hakkında kaleme aldığı risalesinde yer alan rivayetler göz önünde bulundurulduğunda Ca'fer es-Sâdık'ın insanları müt'a nikahı yapmaya teşvik ettiği hatta buna maddi imkanı olmayanlara maddi destek sağladığı görülmektedir. ${ }^{53}$ Bir başka rivayete göre ise Ca'fer es-Sâdık, müt'a nikâhı yapana sevap verilip verilmeyeceği hususunda kendisine sorulan soruya “Şayet kişi yaptığı

\footnotetext{
49 Şeyh Müfîd, Hülâsatü'l-îcâz, 19; Tabatabaî, “ez-Zevâcü'l-müekkat”, 508.

50 Şerif el-Murtazâ, el-İntisâr, 109; Şeyh Müfîd, Hülâsatü'l-îcâz, 19, 20-21.

51 Muhammed b. Muhammed b. en-Nu'mân Şeyh Müfîd, Risâletü'l-müt'a (Beyrut: Dârü'l-Müfîd, 1414), 9.

52 Şeyh Müfîd, Risâletü'l-müt'a, 7 .

53 Şeyh Müfîd, Risâletü'l-müt'a, 7-8; Hür el-Âmilî, Vesâ'ilü'ş-Şîa, 14/442 vd.
} 
müt'a nikâhıyla Allah'ın rızasını arıyor ve bu nikâhı falancaya (Hz. Ömer'e) muhalefet olarak yapıyorsa ona ecir vardır..."54 şeklinde cevap vermiştir. Bu rivayet doğrultusunda Ca'ferîler'e göre müt'a nikâhının ibadet olduğu anlaşılmaktadır. Nitekim konu hakkında Şîi kaynaklarda nakledilen “Hz. Peygamber Miraç gecesi gökyüzüne çıkartılırken Cibril ile karşılaştı̆̆ın ve Cibril'in kendisine Ey Muhammed Allah tabâreke ve teâla buyurdu ki 'ben ümmetinden müt'a nikâhı yapan kadınları affettim" ve "Müminin kemale ermesi ancak müt'a nikâhıyla olur" 55 rivayetlerinde de bu nikâh akdinin kişinin affedilmesi ve imanında kemale ermesinde önemli bir etken olduğuna vurgu yapilmaktadir.

\subsubsection{Müt’a Nikâhının Câiz Olduğunu Gösteren Deliller}

Ca'ferîler, müt'a nikâhının meşruiyetini ispat edebilmek için gerek akli gerekse naklî delillere başvurmaktadırlar. Onların müt’a nikâhının meşruiyeti hakkında ileri sürdükleri delilleri aklî deliller, Kur'an'dan deliller, sünnetten deliller ve icmâdan deliller olmak üzere dört başlık altında toplamak mümkündür.

\subsubsection{Aklî Delil}

Ca'ferîler'e göre, hâlihazırda veya gelecekte zarar barındırmayan tüm menfaatler aklen zaruri olarak caizdir. Onlara göre müt’a nikâhında şimdi veya gelecekte bir zarar söz konusu olmadığından aklen caiz olması gerekmektedir. ${ }^{56}$ Fakat giriş bölümünde de ifade edildiği üzere müt'a nikâhı yapan kadınlar toplum nezdinde kötü yola düşmüş olarak telakki edilmekte ve bu kadınlar için hor görme, küçümseme ve tahkir anlamı içeren "sîgıyye" kelimesi kullanılmaktadır. ${ }^{57}$ Öte yandan halk, Ca'ferî mezhebinde ibadet telakki edilen müt'a nikâhı ile fuhuş arasında sıkı bir bağ kurduğundan bu nikâhı olumlu karşılamamaktadır. ${ }^{58}$ Ayrıca müt’a nikâhının İranlı kadınların erkek himayesi ve sosyal saygınlık gibi beklentilerini karşılamamaktadır. Bundan dolayı da birçok kadının müt’a nikâhına dâimî evlilik beklentisi veya erkeğin bu yöndeki verdiği söze binaen razı olduğu belirtilmektedir. ${ }^{59}$ Müt’a nikahı hakkında bu gibi olumsuzluklar göz önünde bulundurulduğunda bu nikâhın aklen bir zarar barındırmadığı iddiasının doğru olmayacağı aşikardır.

\subsubsection{Kitap'tan Delil}

Ca'ferîler müt'a nikâhının caiz olduğuna dair "Sahip olduğunuz cariyeler müstesna, evli kadınlar da size haram kılındı. Allah'ın size emri budur. Bunlardan başkasını,

54 Bk. Şeyh Müfîd, Risâletü'l-müt'a, 7-8.

55 Hür el-Âmilî, Vesấ'ilü'ş-Şı̂a, 14/442.

56 Şerif el-Murtazâ, el-İntisâr, 109; Şeyh Müfîd, Hülâsatü'l-îcâz, 22.

57 Hâirî, el-Müt' $a, 83$.

58 Hâirî, el-Müt ' $a, 277$.

59 Hâirî, el-Müt 'a, 278-279. 
124 Şiî Mezhepler Arasında İhtilaflı Bir Mesele: Müt’a Nikâhı

namuslu olmak ve zina etmemek üzere mallarınıla istemeniz size helâl kulındı. Onlardan faydalanmanıza karşılık kararlaştırılmış olan ücretlerini verin"60 ayetini delil olarak kullanmaktadırlar. Onlara göre ilgili ayette geçen “تبتغو" "isterseniz" kelimesi sürekli evlilik gibi müt’a evliliğini de kapsamaktadır. Ayrıca bu kelimenin sürekli evlilikten ziyade muvakkat evliliğe delaleti daha açıktır. ${ }^{61}$ Ca'ferîler' in delil olarak kullandıkları yukarıdaki ayet, son dönem Müslümanların çoğunluğuna göre neshedilmiştir. Bu ayeti neshedenin ne olduğu hususunda farklı görüşler ileri sürülmüştür. Bu bağlamda ilgili ayeti nesheden kimilerine göre kadının mirastan alacağı payı belirten miras ayeti (Nisâ sûresi 11-12 ayetleri), kimilerine göre müt'a nikahının yasaklandığını gösteren sünnet, kimilerine göre ise bu nikahın yasaklandığına dair icmâdır. Ca'ferîler'e göre ise bu ayet neshedilmemiştir. ${ }^{62}$

Ca'ferîler yukarıda verilen ayet doğrultusunda kendi görüşlerini desteklemek için şu açıklamaları yapmaktadırlar:

1) Ayette evlilik, isteğe bağlanmıştır. Devamlı nikâhta ise tarafların isteğiyle birlikte veli ve şahitlerin bulunması zorunludur.

2) Ayette nikâhlanmak istenen kadına "جنور "ücret verilmesi gerektiği ifade edilmiştir. Devamlı nikâhlarda ise kadına farîza (الفريضة), Nihle (النحلة) ve sadâk (الصداق) verilmesi gerektiği belirtilmiştir.

3) Hz. Ali, İbn Abbâs, İbn Mes'ût, Zeynelâbidîn, Muhammed Bâkır ve Ca'fer esSâdık'ın ilgili ayeti "belirlenmiş bir süreye kadar" (الى اجل مسمي) ilavesiyle okumuşlardır. ${ }^{63} \mathrm{Bu}$ durumda ilgili ayette kast edilen nikâh, belirli bir süre için yapılan müt'a nikâhıdır.

4) Nisâ sûresi 3. ayetinde İslâm'da meşrû sayılan nikâh türleri açıklanmıştır. Şayet aynı sûresinin 24. ayetinde de devamlı nikâh kast edilecek olursa aynı sürede tekrar yapılmış olacaktır.

5) Ayette geçen "الاستمتاع" kelimesi lügatte her ne kadar zevk alma ve faydalanma anlamlarına gelse de şer'i örfe göre müt'a nikâhının adı olmuştur. Bu kelime özellikle "النساء" kelimesiyle birlikte kullanıldığında bu mana daha belirgindir. ${ }^{64}$

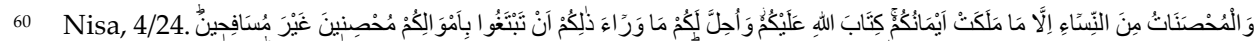

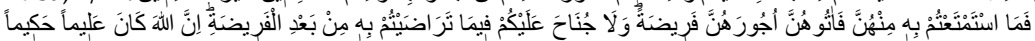

61 Şeyh Müfîd, Hülâsatü'l-îcâz, 22; Hür el-Âmilî, Vesâ'ilü'ş-Şîa, 14/436.

62 Tabatabaî, "ez-Zevâcü'l-müekkat", 511-512.

63 İbn Bâbeveyh, Men lâ yahduruhü'l-fakîh, 3/299; Şeyh Müfîd, Hülâsatü'l-îcâz, 23; Hür el-Âmilî, Vesâ'ilü'ş-Şı̂a, 14/440; Tabatabaî, "ez-Zevâcü'l-müekkat", 511.

64 Şerif el-Murtazâ, el-İntisâr, 110; Şeyh Müfîd, Hülâsatü'l-îcâz, 24
} 
6) “Ücret belirlendikten sonra, onunla ilgili olarak uzlaştı̆̆ınız şeyler konusunda size günah yoktur"65 ayette belirtilen uzlaşı, ücretin artırılması karşılığında yapılan müt’a nikâhının süresinin uzatılmasıdır. Ca' ferî imamlardan gelen rivayetler doğrultusunda Ca'ferî mezhebinde konu hakkında icmâ bulunduğu belirtilmektedir. ${ }^{66}$

Ca'ferîler, yukarıda zikredilen ayetin yanı sıra “...Öyleyse iffetli yaşamaları, zina etmemeleri, gizli dost tutmamalar şartıyla ve ailelerinin de izniyle onlarn nikâhlayın, ücretlerini de âdete uygun olarak verin." 67 ve "Ücretlerini ödediğiniz takdirde bu kadınlarla evlenmenizde sakınca yoktur" 68 ayetlerini de müt'a nikâhının meşruiyeti için delil olarak kullanmaktadırlar. ${ }^{69}$

\subsubsection{Sünnet'ten Delil}

Ca'ferîler'e göre sünnet $\mathrm{Hz}$. Peygamber ve masum imamların söz, fiil ve takrirlerinden oluşmaktadır. ${ }^{70} \mathrm{Bu}$ bağlamda sünnetten deliller arasında Ca'ferî imamların sözlerine de yer verilecektir. Ca'ferî mezhebinde Muhammed Bâkır'dan yapılan bir rivayete göre; kendisine "Hani peygamber, eşlerinden birine gizli bir şey söylemişsi. Eşi bunu başkalarına aktarıp Allah da durumu peygambere açıklayınca peygamber bunun bir kısmını anlattı, bir kısmından vazgeçti." 71 ayetinde geçen Hz. Peygamber'in gizlediği şey hakkında soru sorulması üzerine Muhammed Bâkır, "Hz. Peygamber hür bir kadınla müt'a nikâhı yapmıştı. Bunu Hz. Peygamber'in eşlerinden bir kısmı öğrendi ve onu kötü bir iş yapmakla itham ettiler. Hz. Peygamber bu durum üzerine o kadın benim için helaldir. Onu belli bir süreliğine nikâhladım ve bunu da gizledim eşlerimden bazıları bunu öğrendiler" şeklinde cevap vermiştir. Ca'ferîler konu hakkında Hz. Ali'nin rivayetine de yer vermektedirler. Nitekim Hz. Ali'ye müt'a ayetinin neshedilip edilmemesi

sorulması üzerine o "hayır ayet neshedilmedi şayet Hz. Ömer müt'a nikâhını yasaklamamış olsaydı şakiler dışında kimse zina yapmazdı" şeklinde cevap verdiği rivayet edilmektedir. Ayrıca Ca'ferîler Hz. Ali'nin Beni Neşhel kabilesinden bir kadınla müt’a nikâhı yapmasını da delil olarak göstermektedirler. ${ }^{72}$

Muhammed Bâkır'dan yapılan bir başka rivayete göre Muhammed Bâkır'a müt’a nikâhının hükmü sorulmuş o da müt'a nikâhının Kur'an'da nazil olduğunu ifade ettikten sonra Nisâ sûresi 24. ayetine atıfta bulunmuş ve "benden önce İbn Hattab

\footnotetext{
65 Nisa, $4 / 24$.

66 Şerif el-Murtazâ, el-intisâr, 111.

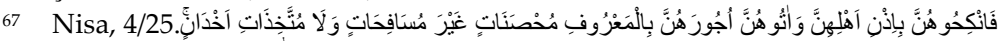

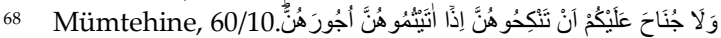

69 Şeyh Müfîd, Hülâsatü'l-îcâz, 23.

70 Âğa Büzürg-i Tahrânî, Hasru'l-ictihad, thk. Muhammed Ali Ensârî (Matbaatu'l-Hiyâm, 1401), 3436; Muhammed Ali Teshîrî, “Usûlü'l-fikh: el-ictihad fî medreseti Ehl-i beyt”, et-Tevhîd 5 (ts.), 49.

71 Tahrîm, 66/3.

72 Bk. Şeyh Müfîd, Hülâsatü'l-îcâz, 24-25; Hür el-Âmilî, Vesâ'ilü'ş-Şîa, 14/440.
} 
126 Şiî Mezhepler Arasında İhtilaflı Bir Mesele: Müt’a Nikâhı

olmasaydı şâkiler zina yapmazdı" demek suretiyle müt'a nikâhının meşruiyetine vurgu yapmiştır. ${ }^{73}$

Ca'ferîler, Hz. Ömer'e nispet edilen “İki müt'a Hz. Peygamber zamanında helaldi ben onları yasaklıyorum ve yapanları cezalandıracă̆ım. Bunlar müt'a nikâhı ve müt'a haccıdır"74 sözüne karşın sahabenin bu durumu reddetmeyip Hz. Ömer'in emrine uymalarını konusunda şu cevabı vermektedirler: Sahabenin bir kısmı her ne kadar bunu kabul etmemişlerse de sayılarının azlığından bunu açık bir şekilde ifade edememiş ve takıyye yapmak suretiyle kendirini gizlemişlerdir. Sahabenin çoğunluğunun ise bu yasağın Hz. Ömer tarafından değil de Hz. Peygamber tarafından yapıldığını ve Hz. Ömer'in bu yasağı tekrar hatırlattığını savunmaktadırlar. ${ }^{75}$ Tûsî (ö. 460/1067), Zeydîyye mezhebinin kurucu imamı olan Zeyd b. Ali (ö. 122/740) tarikiyle rivayet edilen "Hz. Peygamber eşek eti ile müt'a nikâhını yasakladı"76 hadisi yorumlamaktadır. Tûsî, bu rivayetin takiyyeye hamledilmesi gerektiğini çünkü bunun ammenin görüşüne uygun düştüğünü, müt’anın caiz olduğunu gösteren rivayetlerin ise kitabın zahiri ile hak fırkasının icmâına uygun olduğunu bundan ötürü de Zeyd b. Ali'nin şaz rivayetiyle amel edilemeyeceğini ifade etmektedir. ${ }^{77}$

Şeyh Müfîd, "Hz. Peygamber müt'a nikâhını haram kıldı" ve Hz. Ali'den rivayetle "Hz. Peygamber Tebük gazvesinde müt'a nikâhını yasakladı" gibi rivayetlerin ya mürsel78 hadis olduğunu veya bu yönde gelen rivayetlerin senedinde zayıf râvilerin bulunduğunu iddia ederek bu tür rivayetlerin müt’a nikâhının yasaklandığına dair delil olamayacağını ileri sürmektedir. ${ }^{79}$ Buna ilaveten Ca'ferîler, müt'a nikâhının yasaklandığını gösteren hadisler arasında karışıklık olduğunu da kaydetmektedirler. Nitekim müt'a nikâhının yasaklandığını ifade eden kimi rivayetlerde müt'a nikâhının Huneyn gazvesinde kimi rivayetlerde Tebük gazvesinde kimi rivayetlerde ise fetih yılında yasaklandığı belirtilmektedir. ${ }^{80}$ Onlara göre rivayetlerde var olan çelişkili bilgilere dayanılarak müt’a nikâhının yasaklandığı ispat edilemez. Şeyh Müfîd, veli ve iki şahitsiz nikâh olmaz, şahitsiz evlilik yapan zina yapmış olur şeklindeki rivayetleri ise haber-i vâhid oldukları için Nisa sûresi 24. ayetinde belirtilen kati delile muarız edemeyeceğini ifade etmektedir. ${ }^{81}$ Şerif Murtazâ (ö. 436/1044) da müt’a

\footnotetext{
73 Tûsî, el-ístibsâr, 3/141-142.

74 Şerif el-Murtazâ, el-intisâr, 111.

75 Şerif el-Murtazâ, el-íntisâr, 112.

76 Zeyd, el-Mecmû 'u'l-hadîsî ve'l-fikhî, 211.

77 Tûsî, el-ístibsâr, 3/142; Hür el-Âmilî, Vesâ'ilü'ş-Şîa, 14/441.

78 Mürsel: İsnadında, sahâbî olan râvisi veya diğer râvilerinden biri zikredilmeyen hadis. Bk. Salahattin Polat, "Mürsel”, Türkiye Diyanet Vakfı İslâm Ansiklopedisi (13 Ekim 2021).

79 Şeyh Müfîd, Risâletü'l-müt'a, 32-33.

80 Şeyh Müfîd, Risâletü'l-müt'a, 33.

81 Şeyh Müfîd, Risâletü'l-müt'a, 38.
} 
nikâhının yasaklandığına dair rivayetlerin haber-i vâhid olduğunu ve âhâd haberle de amel edilmesinin dinen zorunlu olmadığını kaydetmektedir. Ayrıca müt’a nikâhının yasaklandığına dair ileri sürülen rivayetlerin râvileri hakkında hadis âlimlerinin tenkitlerinin bulunduğunu da belirtmektedir. ${ }^{82}$

\subsubsection{4. İcmâ Delili}

Ca'ferîler, müt'a nikâhını kabul edenler arasında bu nikâhın caiz olduğuna dair icmâ bulunduğunu iddia etmektedirler. Onlara göre müt’a nikâhının caiz olduğu ve neshedilmediği hususunda icmâ bulunmaktadır. Müt'a nikâhının neshedildiğine dair gelen rivayetler ise mütevatir olmayıp ahad haberlerdir. Onlara göre ahad rivayetlerle de Kur'an'ın hükmü -Ca'ferîler'in müt’a nikâhının meşruiyetine delil olarak kullandıkları Nisâ sûresi 24. ayet- neshedilemez. ${ }^{83}$ Fakat Ca' ferîler'in ileri sürdükleri bu icmâ iddiası, Zeydîler'in müt'a nikâhının yasaklanması hususunda Ehl-i beyt arasında icmâın bulunduğuna dair ileri sürdükleri delille çelişmektedir. ${ }^{84} \mathrm{Bu}$ durumda Ca'ferîler'in ileri sürdükleri icmâın mezhep içi icmâ olduğunu söylemek yerinde olacaktır.

\subsubsection{Müt’a Nikâhın Rükünleri}

Ca'ferîler'e göre müt'a nikâhında şahitlerin bulunması şart olmamakla birlikte eşlerin zina töhmetinden kurtulmaları için yapılan nikâhta bir erkek veya bir erkek ile iki kadının şahit olarak bulundurması güzel görülmüştür. ${ }^{85}$ Müt’a nikâhında talakla boşama icmâen gerçekleşmediği gibi bu akitten kaynaklı eşler arasında miras hakkı da doğmaz. ${ }^{86}$ Aynı şekilde mezhepte zâhir görüşe göre zihâr da gerçekleşmez. ${ }^{87}$ Müt'a nikâhı öncesinde belirlenen şartlar geçersiz, akit içerisinde yapılan şartlar ise geçerlidir. Bu bağlamda müt’a nikâhında kadın veya erkek mirasçı olmayı şart koşacak olursa bu şart geçerlidir. ${ }^{88}$ Ayrıca müt’a nikâhında kadına ödenmesi gereken bir nafaka da söz konu değildir. ${ }^{89}$ Müt'a nikâhında her ne kadar erkek azl yapmış bile olsa doğacak çocuğun nesebi ona nispet edilir ve çocuğun nafaka yükümlülüğü erkeğe aittir. Fakat erkek bunu reddedecek olursa liân yapılmaksızın kocanın sözü kabul edilir. ${ }^{90}$

\footnotetext{
82 Şerif el-Murtazâ, el-íntisâr, 110.

83 Şeyh Müfîd, Hülâsatü'l-îcâz, 27.

84 Alevî, el-Câmi'u'l-kâfi fî fikhi'z-Zeydiyye, 4/61.

85 Tûsî, el-İstibsâr, 3/148; Şeyh Müfîd, Risâletü'l-müt'a, 11; Şeyh Müfîd, Hülâsatü'l-îcâz, 50.

86 Tûsî, el-İstibsâr, 3/147; Şeyh Müfîd, Hülâsatü'l-îcâz, 50; Tabatabaî, "ez-Zevâcü'l-müekkat", 508.

87 Hillî, el-Muhtasar, 208; Şeyh Müfîd, Risâletü'l-müt'a, 13-14.

88 Tûsî, el-İstibsâr, 3/149; Hillî, el-Muhtasar, 208; Şeyh Müfîd, Risâletü'l-müt'a, 13-14.

89 Tûsî, el-İstibsâr, 3/152.

90 Hillî, el-Muhtasar, 208; Şeyh Müfîd, Risâletü'l-müt'a, 13-14; Tabatabaî, “ez-Zevâcü'l-müekkat”, 509.
} 


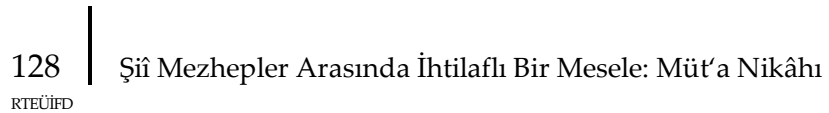

Ca'ferîler'e göre müt'a nikâhının dört rüknü bulunmaktadır. Yapılan müt'a akdinde bu şartlardan birisinin bulunmaması durumunda yapılan müt’a nikâhı geçersizdir. Bu şartlar; sığa, evlenecek kadın, mehir ve zamandır.

\subsubsection{Siğa}

Sığa, erkek ve kadından birisinin müt’a nikâhı yapma teklifinde bulunmasını ifade eden icab ve diğer tarafın da yapılan bu teklife olumlu cevap vermesi olan kabulden oluşmaktadır. Ca'ferîler'e göre icapta "zevvectukî”, "enkahtukî" ve “mette'tukî müddeten keza keza" şeklinde üç lafızdan birisinin kullanılması gerekmektedir. ${ }^{91}$

\subsubsection{Evlenilecek Kadın}

Ca'ferîler'e göre kendisiyle müt‘a nikâhı yapılacak kadın ya Müslüman veya Ehl-i kitap olmalıdır. Devamlı nikâh akdinde Ehl-i kitap kadınlarla evlenilmesini caiz görmeyen Ca'ferîler müt’a nikâhında bunu caiz görmektedirler. Onlara göre müşrik veya nâsibe ${ }^{92}$ kadınla yapılacak müt'a nikâhı geçersizdir. Müslüman kadınla müt'a yapacak erkeğin de Müslüman olması gerekir. Ehl-i kitap kadınla müt’a nikâhı yapmamak müstehaptır. Hür kadınla müt'a yapma imkânı olanın cariyeyle müt'a nikâhı yapması ise mekruhtur. Zina eden kadınla yapılan müt’a nikâhı hakkında mezhepte farklı yaklaşımlar bulunmaktadır. Bir kısım fakih bunu mekruh görmekle birlikte geçerli sayarken diğer bir kısım fakih ise tövbe etmediği sürece bu gibi kadınlarla yapılan nikâhı geçerli görmemektedirler. Ca'ferîler'e göre müt’a nikâhı yapılacak kadınların sayısında üst bir sınır bulunmamaktadır. Kişi dilediği kadar kadınla müt'a nikâhı yapabilir. Onlara göre bakire kadın, babasının iznine gerek duymaksızın kendi rızasıyla müt’a nikâhı yapabilir. Ancak babası olmayan bâkire kadınla müt’a nikâhı yapmak mekruhtur. ${ }^{93}$ Küçüklerin müt'a nikâhı yapmasında babanın izni gerekli görülürken küçükler dışındakilerin müt’a nikâhında babanın izin veya icazeti gerekli değildir. ${ }^{94}$

\subsubsection{Mehir}

Mehir, müt'a nikâh akdinin bir şartı olarak erkeğin kadına ödemek zorunda olduğu para, mal veya menfaattir. ${ }^{95}$ Mehir erkekle kadının üzerinde anlaştıkları

91 Hillî, el-Muhtasar, 207-208; Tûsî, el-İstibsâr, 3/150-151; Şeyh Müfîd, Risâletü'l-müt'a, 45.

92 Nâsibe, Şîa'nın Hz. Ali taraftarlarına düşmanlık besleyenler için kullandığı bir tabirdir. Konu hakkında ayrıntılı bilgi için bk. Mustafa Öz, "Nâsıbe", Türkiye Diyanet Vakfı İslâm Ansiklopedisi (Erişim 29 Eylül 2021).

93 Hillî, el-Muhtasar, 207-208; Tûsî, el-İstibsâr, 3/147,150-151; Şeyh Müfîd, Hülâsatü'l-îcâz, 46-47,51-53; Şeyh Müfîd, Risâletü'l-müt'a, 10, 12-13; Şerif el-Murtazâ, el-İntisâr, 125.

94 Tûsî, el-ïstibsâr, 3/145.

95 Hillî, el-Muhtasar, 214; İbn Bâbeveyh, Men lâ yahduruhü'l-fakîh, 3/261; Şerif el-Murtazâ, el-İntisâr, 124. 
miktar olup bunun bir üst sınırı bulunmamakla birlikte alt sınırı bir dirhem veya bir avuç buğdaydır. ${ }^{96}$ Yapılan akitte mehir belirlendikten sonra bunun peşin ödenme zorunluluğu bulunmamaktadır. Müt’a nikâhı ancak belirli bir ücret karşılı̆̆ında yapılır. Mehir belirlenmeksizin yapılan müt’a nikâhı bâtıldır. ${ }^{97}$

\subsubsection{Zaman}

Yapılacak nikâh akdinde sürenin belirlenmesi müt’a nikâhının şartıdır ve süre gün, ay ve sene şeklinde belirlenmesi gerekmektedir. Zaman belirtilmeksizin bir veya iki defalığına mahsus yapılacak olan müt’a nikâhı sahih değildir. ${ }^{98}$ Bununla birlikte sadece gece veya sadece gündüz veya belirli sayıda birlikte olmak şartıyla yapılan müt'a nikâhı geçerlidir. Zaman belirtilmeksizin mehir konuşulacak olursa bu durum da yapılan müt'a nikâh akdi devamlı nikâha dönüşür. ${ }^{99}$

\subsubsection{Müt’a Nikâhında Kadının Beklemesi Gereken İddet Süresi}

Müt’a nikâhında erkekle kadının üzerinde anlaştıkları süre dolmadan önce müt'a nikâhını yenilemeleri sahih değildir. Şayet eşler süre dolmadan önce tekrar müt'a nikâhı yapmak isterlerse erkek, müt'a nikâhından kalan müddeti kadına hibe etmek suretiyle tekrar müt'a nikâhı yapabilirler. Müt'a nikâhında belirlenen süre bitecek olursa mezhepte eşher ${ }^{100}$ görüşe göre kadının beklemesi gereken iddet iki hayız süresidir. Şayet kadın hayız görmüyorsa bu durumda kadının beklemesi gereken iddet kırk beş gündür. Erkeğin ölmesi durumunda kadının beklemesi gereken iddet süresi hakkında mezhepte iki rivayet bulunmaktadır. Eşbeh ${ }^{101}$ rivayete göre kadının dört ay on gün iddet beklemesi gerekir. Şayet kadın hamile ise doğuma veya doğumla dört ay on günden hangisi fazla ise o süreyi iddet olarak beklemesi gerekmektedir. ${ }^{102}$

Konu hakkında mezhebin görüşü yukarıda açıklandığı gibi olmakla birlikte günümüz İran’da müt’a yapan kadınlar, nikâh süreleri sona erince iddet beklemeden başka bir erkekle evlenebilmek için farklı bir yöntem takip etmektedirler. Hâirî, bu

96 Şeyh Müfîd, Risâletü'l-müt'a, 11; Şeyh Müfîd, Hülâsatü'l-îcâz, 48.

97 Hillî, el-Muhtasar, 207-208; Tûsî, el-İstibsâr, 3/150-151; Şeyh Müfîd, Risâletü'l-müt'a, 10; Şeyh Müfîd, Hülâsatü'l-îcâz, 45 .

98 Hillî, el-Muhtasar, 207-208; Tûsî, el-İstibsâr, 3/150-151; Şeyh Müfîd, Risâletü'l-müt'a, 10; Şeyh Müfîd, Hülâsatü'l-îcâz, 45,47.

99 Hillî, el-Muhtasar, 208; Şeyh Müfîd, Risâletü'l-müt'a, 13-14.

100 Eşher: Bir mesele hakkında iki kavil bulunması durumunda mezhepte kendisiyle fetva verilen müftâbih görüşü göstermek için kullanılmaktadır. Bk. Hillî, el-Muhtasar, 3 (mukaddime içerisinde).

101 Eşbeh: Bir mesele hakkında iki kavil bulunması durumunda mezhep usulünde fetva verilmesi gereken görüşü göstermek için kullanılmaktadır. Bk. Hillî, el-Muhtasar, 3 (mukaddime içerisinde).

102 Hillî, el-Muhtasar, 208; Şeyh Müfîd, Risâletü'l-müt'a, 13-14; Şeyh Müfîd, Hülâsatü'l-îcâz, 50; Tabatabaî, "ez-Zevâcü'l-müekkat”, 508. 
\begin{tabular}{l|l}
130 \\
RTEÜIrID
\end{tabular} Şiî Mezhepler Arasında İhtilaflı Bir Mesele: Müt’a Nikâhı

durumda olan kadının müt'a süresi bittiğinde veya süre henüz dolmamışsa erkek, kalan süreyi ona hibe ederek aynı kadınla yeni bir müt’a nikâh yaptığını ve cinsel birliktelik olmaksızın erkeğin kadından ayrıldığını belirtir. Yapılan bu yeni nikâhta cinsel birliktelik olmadığı için kadının iddet bekleme yükümlülüğü bulunmadığını dolayısıyla kadının başka bir erkekle hemen evlenebileceğini kaydeder. Hâirî, görüştüğü din adamlarının bu yönde yapılan uygulamayı haram görmemekle birlikte buna şiddet bir şekilde karşı çıktıklarını belirtmektedir. ${ }^{103}$

\subsection{Zeydiyye Mezhebi}

Zeydîler'e göre belli bir süreliğine erkeğin kadınla evlenmesi olan müt’a nikâhı haramdır. Müt’a nikâhının haram olduğu hususunda Zeydî fakihlerin icmâsı bulunmaktadır. ${ }^{104}$ İmam Hâdî (ö. 298/911) kendisinin yetişip gördüğü Ehl-i beyt meşayıhından hiçbirinin müt’a nikâhını caiz görmediğini belirtmektedir. ${ }^{105}$ Hâfız Ebû Abdillah el-Alevî (ö. 445/1053) de müt'a nikâhının yasaklanması hususunda Ehl-i beyt arasında icmâın bulunduğunu nakletmektedir. ${ }^{106}$

Zeydîyye mezhebinin kurucu imamı olan Zeyd b. Ali, babası tarikiyle Hz. Ali'den "Nikâh ancak veli ve iki şahitle yapılır. Bir veya iki dirhemle bir iki günlüğüne zinaya benzer şekilde nikâh yapılamaz ve nikâhta şart da ileri sürülemez" ve yine Hz. Ali kanalıyla "Hz. Peygamber Hayber yılında müt'a nikâhını yasakladı" rivayette bulunmaktadır. ${ }^{107}$ Zeyd b. Ali'ye göre müt‘a nikâhı câiz değildir. Zeyd b. Ali tarikiyle rivayet edilen bu hadisler aynı zamanda Zeydîyye mezhebinde en önemli muhaddis ve fakihlerinden olan Ahmed b. İsâ'nın (ö. 247/861) el-Emâlî adlı eserinin yanı sıra daha sonra kaleme alınan Zeydî hadis kaynaklarında da yer almaktadır. ${ }^{108}$ el-Emâlî adlı eserde müt’a nikâhının yasaklandığına dair Zeyd b. Ali tarikiyle yukarıda verilen hadisler dışında konu hakkında birçok hadise de yer verilmiştir. Örneğin "Hz. Peygamber gizli nikâhı (Nikâhu's-sır) yasakladı", " Hz. Ali, müt'a nikâhının yapılmasına dair fetva veren İbn Abbâs'a, (fetvada) acele etme Hz. Peygamber Hayber günü müt'a nikâhı ile eşek etini yasakladı", "Hz. Ali, İbn Abbâs'a Hz. Peygamber'in Hayber günü müt'a nikâhın yasakladığını bilmiyor musun...", "Bir adam İbn Ömer'e gelerek müt'a nikâhı hakkında soru sordu. İbn Ömer, haramdır dedi bunun üzerine adam, falanca helal olduğunu söylüyor dedi. İbn Ömer adama, falanca müt'a nikâhının Hayber günü Hz. Peygamber tarafindan

103 Hâirî, el-Müt' $a$, 97, 307.

104 Müeyyedbillah Ahmed b. Hasan Hârûnî, Şerhü't-Tecrîd fî fikhi'z-Zeydiyye, thk. Yahyâ Sâlim İzzân - Humeyd Câbir Ubeyd (San'a: Merkezü't-Turâs ve'l-Buhûsi'l-Yemenî, 2006), 3/58; Alevî, elCâmi'u'l-kâfî fî fikhi'z-Zeydiyye, 4/62; İbnü'l-Murtazâ, el-Bahru'z-zehhâr, 4/38.

105 Hâdî-İlelhak, Kitâbü'l-ahkâm fi'l-helâl ve'l-harâm, 1/309.

106 Alevî, el-Câmi'u'l-kâfí fî fikhi'z-Zeydiyye, 4/61.

107 Zeyd, el-Mecmû 'u'l-hadîsî ve'l-fikhî, 211.

108 Hâdî-İlelhak, Kitâbü'l-ahkâm fi'l-helâl ve'l-harâm, 1/308; Ahmed b. İsa Ahmed, el-Emâlî, thk. Ali b. İsmail Müeyyed (Beyrut: Dâru'n-Nefâis, 1990), 2/876. 
yasaklandı̆̆ı̆ı biliyor şeklinde cevap verdi. Adam da müt'a haramdır biz de zina eden değiliz dedi." ve "Hz. Peygamber Hudeybiye'nin fethinde müt'a nikâhını üç günlüğ̈̈ne emretti sonrasında ise yasakladı bundan önce ve sonra hiçbir kimseye müt'a nikâhını helal kılmadı."109

Zeyd b. Ali'den sonra Zeydîyye mezhebinde en önemli fakihlerinden aynı zamanda Zeydî Kâsimiyye fıkıh mezhebinin kurucu imamı olan Kasım er-Ressî (ö. 246/860) de müt'a nikâhını caiz görmemektedir. Nitekim Kasım er-Ressî'ye müt’a nikâhının caiz olup olmadığı sorulması üzerine onun müt’a nikâhının helal olmadığını belirttiği ve müt’a nikâhının Hz. Peygamber'in çıktığı bir seferde caiz kılındığını daha sonra ise bu nikâhın Allah tarafından peygamberi lisanıyla yasaklandığını, konu hakkında Hz. Ali'den "Peygamber müt'a nikâhını yasakladı" şeklinde rivayet bulunduğunu kaydedilmektedir. ${ }^{110}$

Aynı şekilde Zeydîyye mezhebi ilk dönem fakih ve muhaddislerinden olan Ahmed b. İsa, Muhammed b. Mansûr (ö. 290/913) ve İmam Hâdî de müt‘a nikâhının haram olduğu konusunda hem fikirlerdir. Örneğin; müt'a nikâhının helal mi yoksa mekruh mu olduğu hususunda kendisine yöneltilen soruya Muhammed $b$. Mansûr'un müt'a nikâhının miras ayetiyle neshedildiğini, veli ile iki adil şahit olmaksızın yapılan nikâhın geçersiz olduğunu belirtmiştir. Mansûr, müt'a nikâhını Kasım er-Ressî ve Ahmed b. İsa'ya sorduğunu onların verdikleri cevabın da bu yönde olduğunu ve Hz. Ali tarikiyle yapılan rivayetle de müt'a nikâhının miras ayetiyle neshedildiğini ifade etmişlerdir. ${ }^{111}$

Zeydî-Hadevî fıkhının kurucu imamı olan Hâdî-İlelhak, Hz. Peygamber döneminde yapılan müt'a nikâhının dâimî nikâhta olduğu gibi velinin izni ve şahitlerin huzurunda yapıldığını ifade etmektedir. Nitekim İmam Hâdî, müt’a nikâhını "velilerin iki adil şahidin huzurunda gerçekleştirdiği nikâh akdi" olarak tanımlamaktadır. Bu görüşünü teyit etmek için "Onlarla karı-koca ilişkisi yaşamanıza karşılık kararlaştırılmış olan ücretlerini (mehirlerini) verin"112 ayetini delil göstermektedir. Nitekim ona göre ilgili ayette kastedilen "velilerin yaptığı nikâh akdiyle karı-koca ilişkisi yaşamanıza karşılık kararlaştırılmış mehri verin" şeklindedir. İmam Hâdî, müt’a nikâhını "kadının, velisi olmaksızın kendini nikâhlaması" şeklinde tanımlayıp bu nikâhı câiz görenleri ise ciddi bir şekilde eleştirmektedir. İmam Hâdî, nikâhın velinin izni olmaksızın gerçekleşmeyeceğine dair "Sizden bekâr olanları, evlendirin"113, "Allah'a ortak koşan erkeklerle de kadınlarınız evlendirmeyin."114 ve "Kocalarıla yeniden evlenmelerine

\footnotetext{
109 Ahmed, el-Emâlî, 2/878-881.

110 Alevî, el-Câmi'u'l-kâfî fî fikhi'z-Zeydiyye, 4/59-60.

111 Alevî, el-Câmi'u'l-kâfî fí fikhi'z-Zeydiyye, 4/61; Hârûnî, Şerhü't-Tecrîd fî fikhi'z-Zeydiyye, 3/59.

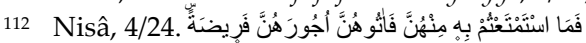

113 Nûr, 24/32.

114 Bakara, 2/221.
} 
132 Şiî Mezhepler Arasında İhtilaflı Bir Mesele: Müt’a Nikâhı

engel olmayın"115 ayetlerini delil göstererek nikâh akdinin velinin iznine bağlı olduğunu ve onun izni olmaksızın nikâh akdinin yapılamayacağını kaydetmektedir. ${ }^{116}$

İmam Hadi, müt'a nikâhında veli şartının aranmaması durumunda haramların meşrulaştırılacağını ifade etmektedir. Ona göre velinin iznine gerek duyulmaması durumunda her zina eden erkek ve kadının kendi aralarında nikâh akdinin bulunduğunu ileri sürerek Allah'ın zina edenler hakkında verdiği cezadan kurtulmaya çalışacaklarını kaydetmektedir. Bu durumda da "Zina eden kadın ile zina eden erkeğin her birine yüz sopa vurun. Allah'a ve âhiret gününe inanıyorsanız, Allah'ın dinini uygulama hususunda o ikisine karşı merhamet duygusuna kapılmayın"117 ayetinin bir anlamının kalmayacağını çünkü bu durumda zina edenin bulunmayacağını belirtmektedir. ${ }^{118} \mathrm{~Hz}$. Ali tarikiyle müt'a nikâhının yasaklandığını rivayet eden İmam Hâdî, Ehl-i beyt imamlarının bu nikâhı câiz görmediklerini, daha sonra ortaya çıan sefihlerin Ehl-i beyt imamları adına yalan uydurarak onların bu nikâhı câiz kabul ettiklerini gösteren rivayetler uydurduklarını belirtmektedir. ${ }^{119}$ Alevî (ö. 445/1053), müt’a nikâhının Hudeybiye gazvesinde ailelerinden uzun süre ayrı kalan sahabe için Hz. Peygamber tarafından mubah kılındığını ve sahabenin de velinin izni doğrultusunda iki şahit huzurunda kadınla belirli gün karşılığında belli bir ücretle evlilik yaptıklarını belirtmektedir. Erkekle kadının evli olacakları gün sayısı artıkça mehirin de artırıldığını ifade eden Alevî, Hz. Peygamber bu gazveden döndükten sonra ashâbını müt'a yapmaktan men ettiğini ve müt’a nikâhı yapanın $\mathrm{Hz}$. Peygamber'e muhalefet ettiğini kaydetmektedir. ${ }^{120}$

Zeydîler Nisâ sûresi 24. ayetini müt’a nikâhının meşruiyeti için delil olarak

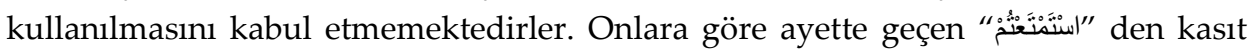
müt'a nikâhından ziyade sahih nikâhlı olan eşle cinsel birlikteliktir. Ayrıca ayette

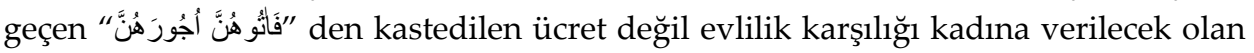
mehirdir. ${ }^{121}$

İmam Hâdî, dedesi Kasım er-Ressî'den müt'a nikâhının Kur'an ve sünnete muhalif olduğunu ve bu nikâhla haramların helal kılındığını nakletmektedir. Müt‘a nikâhında eşlerin bir birlerine mirasçı olamayacağını iddia edenlerin Kur'an'a muhalif hüküm verdiklerini göstermek amacıyla karı-koca arasındaki miras paylarını gösteren ayete yer vermektedir. Nitekim ayette "Yapacakları vasiyetten ve borçtan sonra,

\footnotetext{
115 Bakara, 2/32.

116 Hâdî-İlelhak, Kitâbü'l-ahkâm fi'l-helâl ve'l-harâm, 1/306.

117 Nûr, 24/2.

118 Hâdî-İlelhak, Kitâbü'l-ahkâm fi'l-helâl ve'l-harâm, 1/307.

119 Hâdî-İlelhak, Kitâbü'l-ahkâm fi'l-helâl ve'l-harâm, 1/308-309.

120 Alevî, el-Câmi'u'l-kâfî fî fikhi'z-Zeydiyye, 4/61-62.

121 Hâdî-İlelhak, Kitâbü'l-ahkâm fi'l-helâl ve'l-harâm, 1/308; Alevî, el-Câmi'u'l-kâfi fi fikhi'z-Zeydiyye, 4/61.
} 
eşlerinizin, çocukları yoksa bıraktıklarının yarısı sizindir. Çocukları varsa bıraktıklarının dörtte biri sizindir. Çocuğunuz yoksa sizin de, yapacağınız vasiyetten ve borçtan sonra, bıraktığınızın dörtte biri onlarındır. Çocuğunuz varsa bıraktığınızın sekizde biri onlarındır"122 karı ve kocanın bir birlerine mirasçı olacakları belirtildiğini ifade etmektedir. Ayrıca müt’a nikâhının caiz olduğunu iddia edenlerin kocaların eşlerine ödemesi gereken nafaka ve boşanma sonrası ayette belirtildiği üzere belli bir süre iddet beklemesi gerektiğini gösteren ayetlere muhalif davrandıklarını da belirtmektedir. ${ }^{123}$

İmam Hâdî, İmâmiyye Şîa'sının müt'a nikâhını helal görmekle Allah'ın hükümlerini reddedip bu hükümlere karşı direndiklerini ve Allah'ın koştuğu şarttan daha çok insanın getirdiği şartın zorunlu olduğu ortaya koyduklarını belirtmektedir. Nitekim onlar müt’a nikâhından kaynaklı olacak çocuğun nesebinin babasından olmadığını, ebeveynin çocuklarına veya tam aksi çocukların ebeveynine mirasçı olamayacakları, kadının ölmesi durumunda kocanın eşine, kocanın ölmesi durumunda ise kadının eşine mirasçı olamayacağı ve kadının iddet beklemesine gerek olmadığı gibi hükümler vererek Kur'ân'a muhalif görüşler ileri sürdüklerini ifade etmektedir. ${ }^{124}$

Zeydîler müt'a nikâhını caiz görmemekle birlikte bu nikâhı yapanlara had cezası verilemeyeceğini ifade etmektedirler. Nitekim Alevî, Hz. Peygamber'in "şüpheli durumlarda hadleri düşün" hadisinden hareketle müt'a nikâhı yapanlara had cezası verilemeyeceğini kaydetmektedir. ${ }^{125}$

\section{3. İsmâilîyye Mezhebi}

İsmâilîyye fıkıh mezhebinin kurucusu kabul edilen Kadı Nu’mân (ö. 363/974) müt'a nikâhının Hz. Peygamber tarafından yasaklandığını ifade ettikten sonra konu hakkında Hz. Ali'den "Nikâh ancak veli ve iki şahitle yapılır. Bir veya iki dirhemle bir iki günlü̈̆̈̈ne nikâh yapılmaz. Bu zinadır ve nikâhta şart ileri sürülemez" rivayetine yer vermektedir. İsmâilîler konu hakkında Ca'fer es-Sâdık'tan gelen "Ca'fer es-Sâdık'a müt'a nikâhı hakkında soru soruldu. O da soru sorana müt'a nikâhı nasıl yapılır bana anlat dedi. Soruyu soran 'erkek kadına beninle bir veya iki dirhem karşıllğ̆ında bir seferliğine veya bir iki günlüğ̈̈ne evlenir misin' şeklinde teklifte bulunur ve bu şekilde akit yapılır demesi üzerine Ca'fer es-Sâdık, bu zinadır bunu ancak günahkâr (fâcir) kişi yapar dedi" rivayeti de delil olarak kullanmaktadır. Kadı Nu'mân, müt’a nikâhının batıl olduğuna dair Kur'an'dan ayetlerin bulunduğunu ifade ettikten sonra "Ve onlar ki ırzlarını korurlar. Ancak eşleri ve ellerinin sahip olduğu (câriyeleri) hariç. (Bunlarla ilişkilerden dolayı)

122 Nisa, 4/12.

123 Hâdî-İlelhak, Kitâbü'l-ahkâm fi'l-helâl ve'l-harâm, 1/309-310.

124 Hâdî-İlelhak, Kitâbü'l-ahkâm fi'l-helâl ve'l-harâm, 1/310.

125 Alevî, el-Câmi'u'l-kâfí fî fikhi'z-Zeydiyye, 4/63. 
\begin{tabular}{l|l}
134 \\
RTEÜIrID
\end{tabular} Şiî Mezhepler Arasında İhtilaflı Bir Mesele: Müt’a Nikâhı

kınanmış değillerdir. Kim de bundan ötesini ararsa işte artık onlar haddi aşanlardır"126 ayetini delil olarak göstermektedir. Kadı Nu'mân, ilgili ayetin nikâhın sadece zevce (eş) ve cariyeler için kullanıldığını belirtmektedir. Ayrıca Kadı Nu’mân, Kur’an'da eşlerin bir birine varis oldukları ve boşanan kadının belli bir süre iddet beklemesi gerektiği ve eşlerin ayrılmasını gerekli kılan talakla ilgili hükümlerin bulunduğunu ve müt’a nikâhının ise ayetlerde belirtilen hükümlerin aksine yapılan bir akit olduğunu kaydetmektedir. Kadı Nu'mân bu nikâhı caiz görenlerin müt'a nikâhını "erkek ve kadının belli bir süre evlilik hayatı sürmeleri ve süre bittiğinde talaka gerek olmaksızın bir birlerinden ayrıları" şeklinde tanımladıklarını ifade etmektedir. Kadı Nu'mân müt’a nikâh akdini caiz görenlerin bu nikâhtan kaynaklı bir çocuğun olması durumunda nesebinin babasına nispet edilemeyeceği, kocanın kadına nafaka ödeme zorunluluğunun bulunmadığını ve bir birlerine mirasçı olamayacaklarını ifade ettikten sonra müt’a nikâhının bilinen şekliyle zina olduğunda kuşku bulunmadığını belirtmektedir. ${ }^{127}$

\section{SONUÇ}

İslam öncesi Arap toplumlarında var olduğu bilinen müt’a nikâhının İslam'ın teşrî kıldığı bir evlilik akdi olarak sunulması doğru değildir. Bu bağlamda İslam'ın teşrî kılmadığı müt’a nikâhı hakkında Ca'ferîler'in tartışmaya açtı̆̆ı nesih tartışmasının da doğru olmadığı anlaşılmaktadır. Konu hakkında asıl tartışılması gereken Hz. Peygamber tarafından izin verilen müt’a nikâhının daha sonra yasaklanıp yasaklanmadığı meselesidir.

Ca'ferîler tarafından müt'a nikâhının meşruiyeti için delil gösterilen Nisâ sûresi 24. ayetin anlaşılması ve yorumlamasında Ca'ferîler' in, kendileri dışındaki fakihlerin ittifakına aykırı bir şekilde davrandıkları görülmektedir. Nitekim ilgili ayetin devamlı evlilik hakkında olduğu hususunda gerek Sünnî gerekse Ca'ferîler dışındaki Şiî fıkıh mezheplerinin ittifakı bulunmaktadır.

Ca'ferîler'in müt'a nikâhının meşruiyeti hakkında ileri sürdüğü "hâlihazırda veya gelecekte zarar barındırmayan tüm menfaatler aklen zaruri olarak caizdir" yönündeki aklî delilin müt’a nikâhı uygulamasıyla uyuşmadığı, müt’a nikâhı yapan kadınların toplumdan dişlanmasının yanı sıra birçok haktan da mahrum bırakılmalarına sebep olduğu anlaşılmaktadır. Dolayısıyla Ca'ferîler'in aksine bu nikâh akdinin aklen câiz olmadığını söylemek isabetli olacaktır.

Ca'ferîler' in müt'a nikâhının meşruiyeti hakkında icmâ bulunduğuna dair ileri sürdüğü delilinin yerinde olmadığı, aksine Ca'ferîler dışındaki fıkıh mezheplerinin müt’a nikâhının yasaklandığına dair icmâın bulunduğunu söylemek mümkündür.

126 Mü'minûn, 5-7.

127 Kadı Nu'mân, De'âimü'l-İslâm, 2/228-229; Kadı Nu'mân, İktisâr, 81. 
Ayrıca Zeydîler'in müt'a nikâhının yasaklanması hususunda Ehl-i beyt arasında icmâın bulunduğuna dair ileri sürdükleri delille, Ca'ferîler'in icmâ iddiası çelişmektedir.

Ca'ferîler'in müt'a nikâhının caiz olduğuna dair Ehl-i beyt imamlarının ittifak halinde olduğuna dair rivayetleri, Ca'ferîler gibi Ehl-i beyt kaynaklarından beslenen Zeydî ve İsmâilî fıkıh mezheplerinde bulunan rivayetlerle çelişmektedir. Nitekim Zeydîler'in müt’a nikâhının yasaklanması hususunda Ehl-i beyt'in icmâsının bulunduğu yönündeki iddialarının yanı sıra bu iki fıkıh mezhebinin kaynaklarında gerek Hz. Ali ve gerekse Ca'fer es-Sâdık'tan yapılan rivayetlerde müt'a nikâhının yasaklandığı görülmektedir. Bu da konu hakkında Ehl-i beyt imamları kanalıyla gelen rivayetlere ihtiyatla yaklaşılması gerektiğini göstermektedir.

Kur'ân ve sünnette müt’a nikâhının hükümlerini belirleyen açıklayıcı bir bilgi bulunmadığı için müt’a evliliğinin çerçevesinin devamlı nikâhla cariyelerle evlilik hükümleri doğrultusunda Şiî fakihler tarafından icâre (kira) akdi çerçevesinde belirlendiği anlaşılmaktadır.

Zeydîler, Hz. Peygamber döneminde yapılan müt'a nikâhıyla Ca'ferîler'in caiz gördüğ̈̈ müt‘a nikâhın arasında farklılıklar bulunduğunu kaydetmektedirler. Zeydîler'e göre Hz. Peygamber döneminde yapılan müt’a nikâhı veli ve iki şahit huzurunda gerçekleştirilmekteydi. Fakat Ca'ferîler müt’a nikâh akdinde veli ve şahitlerin bulunmasını gerekli görmemektedirler.

Zeydî ve İsmâilîler, müt’a nikâhını câiz görenlerin bu nikâhtan kaynaklı olacak çocuğun nesebinin babasına nispet edilemeyeceği, ebeveynin çocuklarına veya tam aksi çocukların ebeveynine mirasçı olamayacakları ve kadının iddet beklemesine gerek olmadığı gibi hükümler verdiklerini ifade etmektedirler. Fakat Ca'ferî kaynaklarına bakıldığında bu gibi iddiaların yerinde olmadığı görülmektedir. Nitekim onlara göre müt’a nikâhında her ne kadar erkek azl yapmış bile olsa doğacak çocuğun nesebi erkeğe nispet edilir ve çocuğun nafaka yükümlülüğü ona aittir. Erkeğin ölmesi durumunda çocuk ona mirasçı olabilmektedir. Fakat erkek bunu reddedecek olursa liân yapılmaksızın erkeğin sözü kabul edilir. Ayrıca Ca'ferî mezhebine göre müt’a nikâhı yapan kadının beklemesi gereken iddet iki hayız süresidir. Şayet kadın hayız görmüyorsa bu durumda kadının beklemesi gereken iddet kırk beş gündür. Ancak tedricî bir gelişimle çerçevesi belirlenen müt'a nikâhının Zeydî ve İsmâilî fakihlerin dönemlerinde yukarıda belirtildiği şekilde uygulandığını söylemek de mümkündür.

Ca'ferîler' in Hz. Ömer'in müt'a nikâhı ve müt’a haccını kendisine nispet ederek yasaklaması ve sahabenin de bu durumu reddetmeyip Hz. Ömer'in emrine uymaları konusunda yaptıkları yorum isabetli değildir. Nitekim onlara göre Hz. Ömer'in 
136 Şiî Mezhepler Arasında İhtilaflı Bir Mesele: Müt’a Nikâhı

RTEÜIFD

yaptığı bu yasaklamalar her ne kadar bazı sahâbeler tarafından kabul edilmemişse de sayılarının az oluşundan bunu açık bir şekilde ifade edememiş ve takıyye yapmak suretiyle kendilerini gizlemişlerdir. Fakat bir kısım sahâbenin hac konusunda Hz. Ömer'den farklı düşünmeleri ve onun içtihadına karşı çıkıp görüşüne katılmamaları Ca'ferîler'in yaptıkları bu izahla çelişmektedir. Bu durumda müt’a nikâhının $\mathrm{Hz}$. Peygamber tarafından yasaklandığı ve Hz. Ömer'in bu yasağ1 tekrar hatırlattığını sahabenin de bundan haberdar olduğu için ona karşı çıkmadıklarını söylemek isabetli olacaktır. 
\begin{tabular}{r|r} 
AHMET EKINCI & 137 \\
RTEüirD
\end{tabular}

\section{KAYNAKÇA}

Ahmed, Ahmed b. İsa. el-Emâlî. thk. Ali b. İsmail Müeyyed. 3 Cilt. Beyrut: Dâru'nNefâis, 1. Basım, 1990.

Ahterî, Muslihuddin Mustafa. Ahterî-i kebîr. İstanbul: Matbaatu Âmire, 1310.

Alevî, Muhammed b. Ali b. Hüseyin. el-Câmi'u'l-kâfî fî fikhi'z-Zeydiyye. 8 Cilt. Yemen: Müessesetü'1-Mustafa es-Sekafiyye, I., 2014.

Atî, Hammûdah 'Abd al-. The Family Structure in İslam, ts.

Bakkaloğlu, M. K. Abdüssamet. Câhiliye Dönemi Âile Hukuku. İstanbul: Marmara Üniversitesi Sosyal Bilimler Enstitüsü, Yüksek Lisans Tezi, 1995.

Beyhakî, Ebû Bekr Ahmed b. el-Hüseyn b. Ali. es-Sünenü'l-kübrâ. thk. Muhammed Abdulkadir Ata. 10 Cilt. Beyrut: Dâru'l-Kütübi'l-İlmiyye, 3. Basım, 1424.

Canan, İbrahim. Namus Fitnesi Mut'a Nikâhı. İstanbul: Timaş Yayınları, 2011.

Cevâd, Ali. el-Mufassal. 20 Cilt. Beyrut: Dâru's-Sâkî, 4. Basım, 2001.

Çakır, Adalet. Mut'a Nikahının Tarihi Gelişmesi ve İslâm Hukukundaki Yeri. İstanbul: Marmara Üniversitesi, Yüksek Lisans, 1994.

Dalkıran, Sayın. “İmamiyye Şîası'nın Mut'a Nikahı Uygulamasına Karşı Ahmet Feyzi'nin Eleştirileri”. Atatürk Üniversitesi İlahiyat Fakültesi Dergisi 27 (2007), 116.

Demircan, Adnan. “Cahiliye ve Hz. Peygamber Dönemi Uygulamalarıyla Nikâh". Diyanet İlmi Dergi 49/3 (01 Eylül 2013), 21-42.

Günaltay, M. Şemseddin. "Kable'l-İslâm Araplarda İctimâî Aile". Darülfünun İlahiyat Fakültesi Mecmuası 1/4 (1926).

Hâdî-İlelhak, Yahya b. Hüseyin. Kitâbü'l-ahkâm fi'l-helâl ve'l-harâm. thk. Murtazâ b. Zeyd Mahatvarî. 2 Cilt. San'a: Mektebetü Bedr, 2. Basım, 2014.

Hâirî, Şehlâ. el-Müt'a ez-zevâcü'l-müekkat inde'ş-Şî'a, hâletü Iran 1978-1982. çev. Fâdî Hammûd. Beyrut: Şirketü'l-Matbûat, 12. Basım, 2007.

Hârûnî, Müeyyedbillah Ahmed b. Hasan. Şerhü't-Tecrîd fî fikhi'z-Zeydiyye. thk. Yahyâ Sâlim İzzân - Humeyd Câbir Ubeyd. 6 Cilt. San'a: Merkezü't-Turâs ve'1-Buhûsi'1Yemenî, 1. Basım, 2006.

Hillî, Ebü'l-Kâsım Necmüddîn Ca'fer b. el-Hasen b. Ebî Zekeriyyâ Yahyâ. el-Muhtasar. Bağdat: Mektebetü'l-Ehliyye, 1383. 


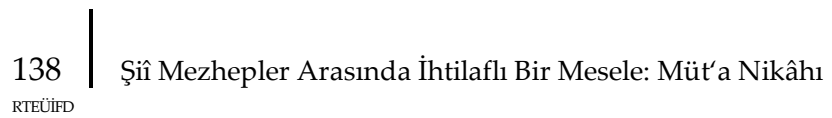

Hillî, Ebü'l-Kâsım Necmüddîn Ca'fer b. el-Hasen b. Ebî Zekeriyyâ Yahyâ. Şerâ'i 'u'lİslâm. thk. Seyyid Sâdık Şîrâzî. 4 Cilt. Beyrut: Müessesetü'l-Vefâ, 2. Basım, 1409.

Hür el-Âmilî, Muhammed b. el-Hasen b. Ali. Vesấilü'ş-Şîa. 22 Cilt. Tahran: Mektebetü'l-İslâmiyye, 4. Basım, 1397.

İbn Bâbeveyh, Muhammed b. Ali b. Hüseyin. Men lâ yahduruhü'l-fakîh. 4 Cilt. Beyrut: Müessesetü'l-A'lemî li'l-Metbûat, 1. Basım, 1406.

İbn Manzûr, Muhammed b. Mükerrem b. Ali b. Ahmed. Lisânü'l-Arab. 15 Cilt. Beyrut: Dâru Sâdır, 3. Basım, 1414.

İbnü'l-Murtazâ. el-Bahru'z-zehhâr. 6 Cilt. Beyrut: Dâru'l-Kütübi'l-İlmiyye, 1. Basım, 2001.

Kadı Nu'mân, Nu'mân b. Ebî Abdillah Muhammed b. Mansûr. De'âimü'l-İslâm. thk. Asıf b. Ali Feyzî. 2 Cilt. İskenderiyye: Dâru'l-Meârıf, 1383.

Kadı Nu'mân, Nu'mân b. Ebî Abdillah Muhammed b. Mansûr. İktisâr. Beyrut: Dâru'lEvdâ', 1. Basım, 1416.

Kaşıkçı, Osman. “Mut’a Nikâhı". Türk Hukuk Tarihi Araştırmaları 3 (2007), 43-58.

Köse, Saffet. “Ca'ferîlikte Mut’a ve Ona Karşı Sünnî Duruş”. Marife 3 (2008), 75-120.

Meşinci, Yasemin. Mut'a Nikahı ile İlgili Hadislerin Tespit ve Tenkidi. Adana: Çukurova Üniversitesi Sosyal Bilimler Enstitüsü, Yüksek Lisans Tezi, ts.

Muğniyye, Muhammed Cevad. el-Fıkh ale'l-mezâhibi'l-hamse. Tahran: Müessesetü'sSâdık, 5. Basım, ts.

Öz, Mustafa. “Nâsıbe”. Türkiye Diyanet Vakfı İslâm Ansiklopedisi. Erişim 29 Eylül 2021. https://islamansiklopedisi.org.tr/nasibe

Öztürk, Mustafa. "Sünni ve Şii Kaynaklarda Mut'a Nikâhı Tartışması”. İslâmiyât 8/3 (2005), 95-120.

Polat, Salahattin. "Mürsel”. Türkiye Diyanet Vakfı İslâm Ansiklopedisi. 13 Ekim 2021. https://islamansiklopedisi.org.tr/mursel

Râzî, Muhammed b. Ebû Bekir. Muhtârü's-sihâh. Beyrut: Mektebetü'l-Asriyye, 5. Basım, 1420.

Sanânî, Ahmed b. Kasım el-Ansî. et-Tâcü'l-müzheb li ahkâmi'l-mezheb Şerhu Metni'lEzhâr. 4 Cilt. Yemen: Dâru'l-Hikmeti'l-Yemâniyye, 1414.

Şerif el-Murtazâ, Ali b. el-Hüseyin b. Musa b. Muhammed. el-íntisâr. Kum: Menşûrâtü'ş-Şerif el-Murtaza, 1391. 
Şeyh Müfîd, Muhammed b. Muhammed b. en-Nu'mân. Hülâsatü'l-îcâz. Beyrut: Dârü'l-Müfîd, 2. Basım, 1414.

Şeyh Müfîd, Muhammed b. Muhammed b. en-Nu'mân. Risâletü'l-müt'a. Beyrut: Dârü'l-Müfîd, 2. Basım, 1414.

Tabatabaî, Seyyid Kazım. "ez-Zevâcü'l-müekkat tarîkun şer'î li-teârufi'z-zevceyni kable'n-nikâhi'd-dâim”. Dinlerde Nikâh Milletlerarası Tartışmalı İlmî Toplantı. 503515. İzmir, 2012.

Tahrânî, Âğa Büzürg-i. Hasru'l-ictihad. thk. Muhammed Ali Ensârî. Matbaatu'1Hiyâm, 1401.

Teshîrî, Muhammed Ali. “Usûlü'l-fıkh: el-ictihad fî medreseti Ehl-i beyt". et-Tevhîd 5 (ts.), 42-56.

Tûsî, Ebû Ca'fer Muhammed b. el-Hasen b. Ali. el-İstibsâr. thk. Seyyid Hasan Mûsevî. 4 Cilt. Necef: Dâru'l-Kütübi'l-İslamiyye, 2. Basım, 1376.

Yılmaz, Süleyman. Ehl-i Sünnet ve Şî̂ Caferî Müfessirlerine Göre Mut'a Nikâhı. Yozgat: Bozok Üniversitesi, Yüksek Lisans, 2017.

Zeyd, Zeyd b. Ali. el-Mecmû'u'l-hadîsî ve'l-fikhî. thk. Abdullah b. Hamûd el-İzzî. Yemen: Mektebetü İmam Zeyd b. Ali, 1. Basım, 2002. 